\title{
Identification of single Ru(II) ions on ceria as a highly active catalyst for abatement of NOx pollutants
}

\author{
Konstantin Khivantsev, ${ }^{a *} \dagger$ Nicholas R. Jaegers, ${ }^{a} \dagger$ Hristiyan A. Aleksandrov, ${ }^{\mathrm{b}} \dagger^{*}$ Inhak Song, ${ }^{a}$ Xavier \\ Isidro Pereira-Hernandez, ${ }^{a}$ Jinshu Tian ${ }^{a}$, Libor Kovarik, ${ }^{a}$ Georgi N. Vayssilov, ${ }^{b}{ }^{\text {Yong Wang }}{ }^{\mathrm{a}, \mathrm{c}^{*}}$ and \\ János Szanyi ${ }^{a}{ }^{*}$
}
[a] Dr. Konstantin Khivantsev, Dr. Libor Kovarik, Dr. Nicholas R. Jaegers, Dr. InHak Song, Dr. Jinshu Tian, Dr. Xavier I. Pereira Hernandez, Dr. Yong Wang, Dr. Janos Szanyi,
Institute for Integrated Catalysis
Pacific Northwest National Laboratory
Richland, WA 99352 USA
Emails (correspondence to): Konstantin.Khivantsev@pnnl.gov, Haa@chem.uni-sofia.bg, Yong.Wang@pnnl.gov, Janos.Szanyi@pnnl.gov, † denotes equal contribution

[b] Professor Hristiyan A. Aleksandrov, Professor Georgi N. Vayssilov, Sofia University "St. KI. Ohridski", Faculty of Chemistry and Pharmacy

J. Bourchier blvd, 1126, Sofia, Bulgaria

[c] Professor Yong Wang, Voiland School of Chemical Engineering and Bioengineering

Washington State University

Pullman, WA 99164 USA

\begin{abstract}
Atom trapping allows to prepare catalysts with atomically dispersed $\mathrm{Ru}$ ions anchored to the ceria support. The resulting catalysts free of expensive noble metals such as $\mathrm{Pt}, \mathrm{Pd}, \mathrm{Rh}$ (whose prices are $\sim 8-60$ times higher than $\mathrm{Ru}$ on the per-molar basis) with $\mathrm{Ru}$ loadings of only $0.25-0.5 \mathrm{wt} \%$ show excellent activity in industrially important catalytic NO oxidation reaction, a critical step that requires use of relatively large loadings of expensive noble metals in diesel aftertreatment systems. $\mathrm{Ru}_{1} / \mathrm{CeO}_{2}$ catalysts are stable during continuous cycling, ramping and cooling as well as presence of moisture. Furthermore, $\mathrm{Ru}_{1} / \mathrm{CeO}_{2}$ shows excellent $\mathrm{NOx}$ storage properties during cold start, with improved $\mathrm{NO}$ adsorption compared with the best described $\mathrm{Pd} /$ Zeolite $\mathrm{NO}$ adsorbers with $\sim 2-3$ times higher Pd loadings. We clarify the location of Ru(II) ions on the ceria surface and identify mechanism of NO oxidation (as well as reactive storage) using DFT calculations and in-situ DRIFTS/Massspectroscopy measurements. Furthermore, we show the possible applications of $\mathrm{Ru}_{1} / \mathrm{CeO}_{2}$ in gasoline engines for $\mathrm{NO}$ reduction by $\mathrm{CO}$ : only $0.1 \mathrm{wt} \%$ of atomically dispersed $\mathrm{Ru}$ is sufficient to achieve high activity at low temperatures. With the aid of excitation-modulation insitu infra-red measurements, we uncover the elementary steps of NO reduction by $\mathrm{CO}$ on an atomically dispersed ceria-supported catalyst. Our study highlights the potential applicability of single-atom catalysts to industrially relevant $\mathrm{NO}$ and $\mathrm{CO}$ abatement.
\end{abstract}

Air pollution is one of the main issues to tackle in environmental science and catalysis [1-3]. Deteriorating air quality is directly related to toxic $\mathrm{NO}_{x}$ emissions, the majority of which are produced by vehicles exhaust. There clearly exists the urgent need to decrease emissions from engines and develop catalytic materials for NOx abatement based on less expensive (noble) metals with improved atom economy. NO oxidation is critical for environmental catalysis in diesel aftertreatment systems because $\mathrm{NO}_{2}$ formation is important in lean $\mathrm{NO}_{\mathrm{x}}$ reduction [34-38]. Furthermore, $\mathrm{NO}_{2}$ facilitates ammonia selective catalytic reduction $(\mathrm{SCR}$ ) (so-called "fast" $\mathrm{SCR}$, with an ideal 1:1 ratio between $\mathrm{NO}$ and $\mathrm{NO}_{2}$ ) and lean $\mathrm{NO}_{x}$ storage (in this case, $\mathrm{NO}$ must first be oxidized to $\mathrm{NO}_{2}$ in order to be stored on LN traps materials). Best catalysts for NO oxidation typically contain a few wt\% percent of expensive $\mathrm{Pt}$ and $\mathrm{Pd}$ [34-38]. Pt costs $\sim 1,000$ USD/ounce whereas $\mathrm{Pd}$ costs $\sim 2,600$ USD/ounce (note that $\mathrm{Pt}$ is approximately $\sim 2$ times heavier, so per molar basis the price is only $\sim 1.3$ higher for $\mathrm{Pd}$ than for $\mathrm{Pt}$ ).

In recent decade, the so-called single-atom materials with efficient utilization of single metal atoms/ions have been introduced that may offer promising alternatives and unusual reactivities compared to traditional nanoparticle catalysts. For example, thermally stable atomically dispersed $\mathrm{Pt}$ materials on ceria have been prepared via atom trapping approach at $800{ }^{\circ} \mathrm{C}$ [28-31]. We now extended this synthesis to Pd. We also turned our attention to another transition metal Ruthenium whose price is only $\sim 300$ USD per ounce and whose molecular weight is similar to that of $\mathrm{Pd}$ and $\mathrm{Rh}$ (Rh, on the other hand, costs $\sim 20,000$ USD per ounce, almost $\sim 60$ times more on the molar basis than $\mathrm{Ru}$; $\mathrm{Ru}$ is approx $\sim 8-10$ times cheaper on per-molar basis than $\mathrm{Pt}$ and $\mathrm{Pd}$ ). Taking advantage of the atom trapping approach, we prepared isolated $\mathrm{Pd}, \mathrm{Pt}$ and $\mathrm{Ru}$ atoms on ceria in equivalent molar amounts (atom loading per surface area of ceria) with 1 wt $\% \mathrm{Pt}, 0.5 \mathrm{wt} \% \mathrm{Ru}$ and $0.5 \mathrm{wt} \% \mathrm{Pd}$ on ceria. We note that ceria materials with isolated $\mathrm{Ru}(\mathrm{II})$ have not been prepared or characterized before via the described method. We observed pronounced stabilization of ceria surface area after heating at 800 ${ }^{\circ} \mathrm{C}$ and producing atomically dispersed M/Ceria materials as opposed to undoped ceria (Tab. S1). Doping ceria with these ions produces stable materials that can survive heating in air at $800^{\circ} \mathrm{C}$ in agreement with our latest findings [42]. HAADF-STEM images of $\mathrm{Pd}, \mathrm{Pt}$ and $\mathrm{Ru}$ supported ceria materials (Fig. 1A-C) show crystalline ceria nanoparticles with no noble metal nanoparticles. In the case of Pt on ceria we can identify single Pt atoms located on the surface of ceria (Fig. 1B) However, in the case of Pd and $\mathrm{Ru}$, although the contrast is poor, on sufficiently thin parts of ceria nanoparticles tilted slightly off the zone-axis (to decrease scattering from bright $\mathrm{Ce}$ atom columns), we could in fact identify single Ru atoms (shown by arrows on the surface of different ceria crystallites in Fig. 1C). In all 3 cases, EDS maps clearly reveal 

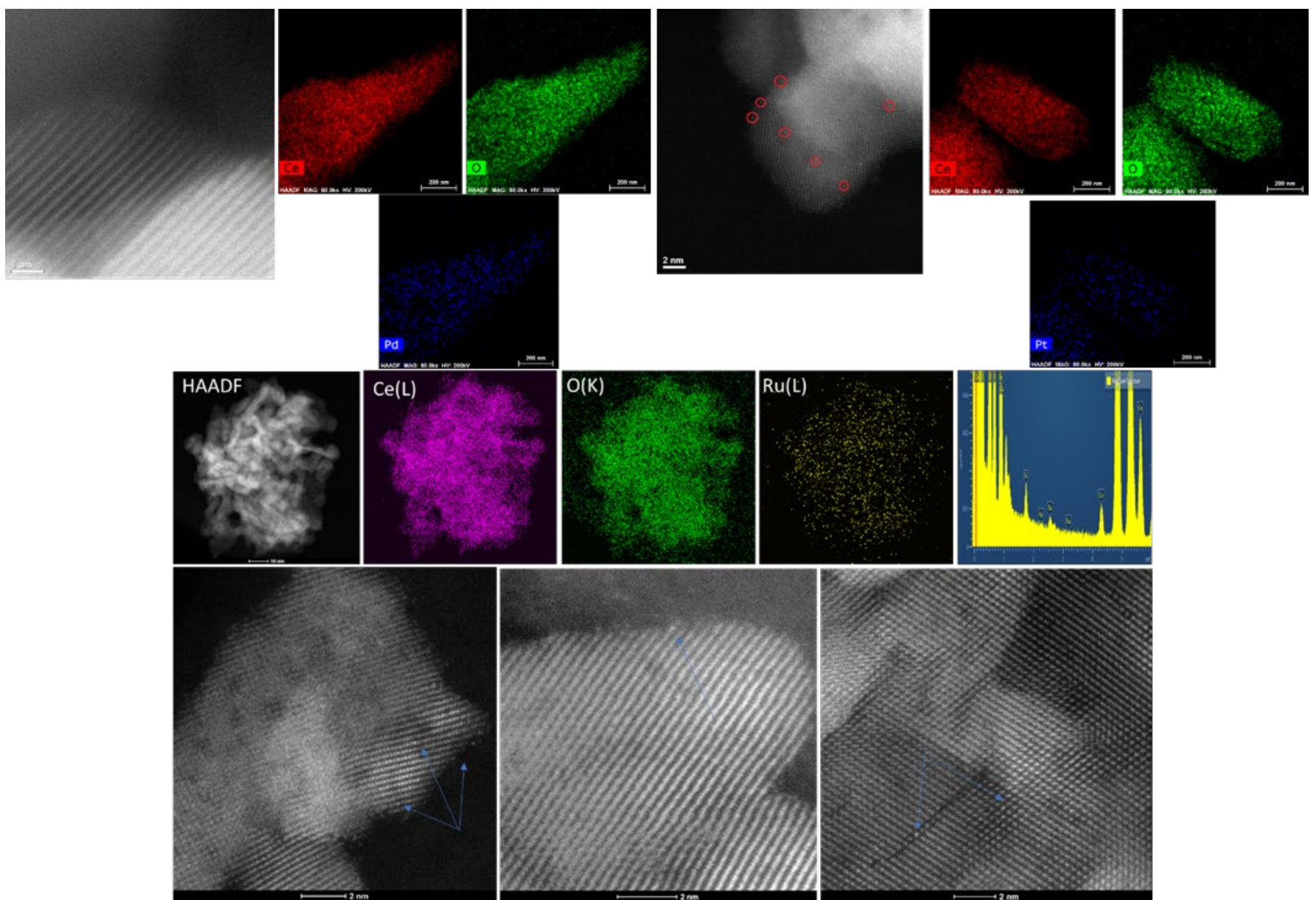

Figure 1. HAADF-STEM images and corresponding EDS maps of $0.5 \mathrm{wt} \% \mathrm{Pd} / \mathrm{CeO}_{2}, 1 w t \% \mathrm{Pt} / \mathrm{CeO}_{2}$ and $0.5 \mathrm{wt} \% \mathrm{Ru} / \mathrm{CeO}$. Single Pt and Ru atoms are highlighted with red circles and blue arrows, correspondingly.

presence of Pd, Pt and Ru well-dispersed throughout the sample, further confirming our suggestion of the atomic dispersion of the said metals on ceria. We tested these model single-atom materials for $\mathrm{NO}$ oxidation. Pt and Pd showed relatively low NO oxidation activities (Figs. S1,S2). To our delight, $0.5 \mathrm{wt} \%$ Ru/ceria sample showed excellent $\mathrm{NO}$ oxidation activity in the steamcontaining lean $\mathrm{NO} / \mathrm{O}_{2} / \mathrm{N}_{2}$ stream (Fig. 2).

The sample shows stable performance with little hysteresis going down, up and then back down in temperature (from $650^{\circ} \mathrm{C}$ to 300 $\left.{ }^{\circ} \mathrm{C}\right)$. Activity maximum is observed at $\sim 345{ }^{\circ} \mathrm{C}$, with $\sim 75 \%$ conversion of $\mathrm{NO}$, comparing very favourably with commercial
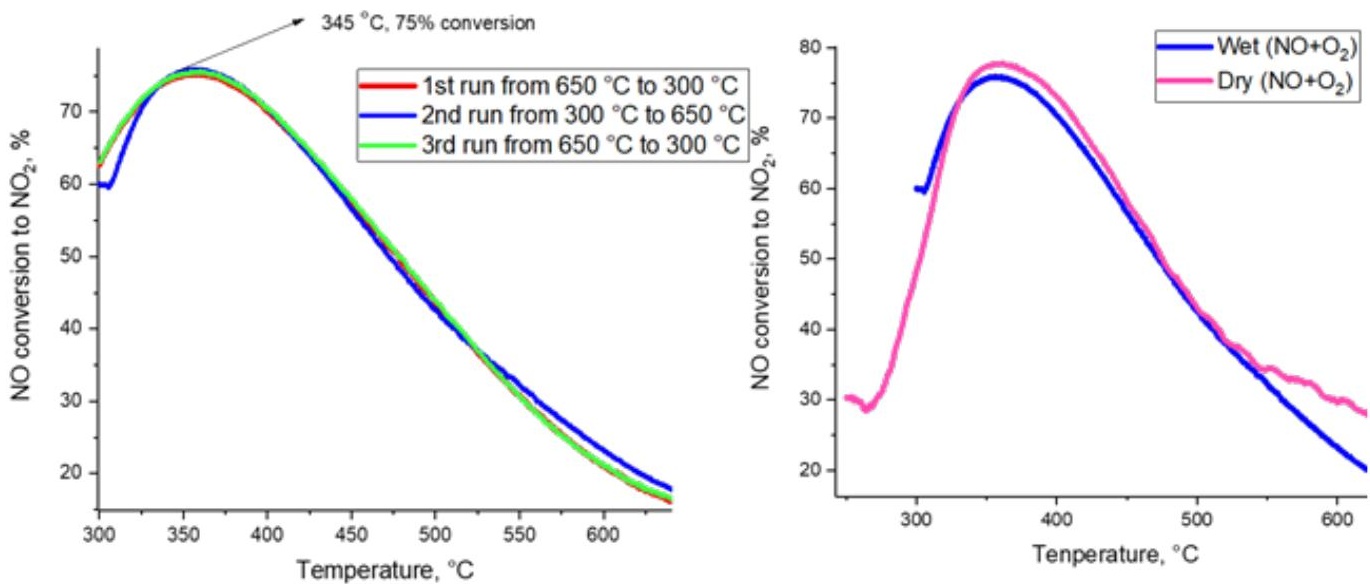

Figure 2. NO oxidation performance of $\mathrm{A} .0 .5 \mathrm{wt} \% \mathrm{Ru} / \mathrm{CeO}_{2}\left(3\right.$ continuous runs from 650 to 300,300 to 650 and then 650 to $300{ }^{\circ} \mathrm{C}$ showing stable $\mathrm{NO}$ oxidation performance in the presence of $\sim 3 \% \mathrm{H}_{2} \mathrm{O}, 120 \mathrm{mg}$ catalyst, $470 \mathrm{ppm} \mathrm{NO}, 13 \% \mathrm{O}_{2}$, total flow 300 sscm/min, GHSV $\sim 150 \mathrm{~L} / \mathrm{g} * \mathrm{hr}$. B. Comparison of wet and dry $\mathrm{NO}$ oxidation on aged $0.5 \mathrm{wt} \% \mathrm{Ru} / \mathrm{CeO} 2$ going up in temperature to 650 ${ }^{\circ} \mathrm{C}$ (conditions are identical to A; dry experiments were carried out with the same NO and oxygen concentrations but in the absence of water) 
DOC materials tested under similar conditions [Fig. S21]. We also tested this sample in the dry NO oxidation (Fig. 2) and did not observe any prominent water influence on the NO oxidation activity. We hypothesized that this remarkable NO oxidation activity only by single-atom $\mathrm{Ru}$ (and not $\mathrm{Pt}$ and $\mathrm{Pd}$ ) is related to the presence of labile active lattice oxygen of ceria and the ability of $\mathrm{Ru}$ ions to form ruthenium nitrosyl complexes. If Ru-NO complexes indeed form, then Ru-ceria should be able not to just oxidize NO but also store NO at lower temperatures: this storage is critical during vehicle cold-start and idle operation the temperatures of exhaust are lower $\left(\sim 100-120^{\circ} \mathrm{C}\right)$ and no known catalyst can catalyze NOx removal at this temperature. More
Pd basically store very little NO, consistent with lack of strong bond formation between $\mathrm{NO}$ and $\mathrm{Pd}(\mathrm{II}) / \mathrm{Pt}$ (II) on ceria. $0.5 \mathrm{wt} \%$ $\mathrm{Ru}_{1} / \mathrm{CeO}_{2}$, however, showed very high $\mathrm{NO}$ uptake (Fig. 3) with full consumption of $\mathrm{NO}$ (level $\sim 0 \mathrm{ppm}$ ) at $100^{\circ} \mathrm{C}$.

Its performance is better than performance of $\mathrm{Pd} / \mathrm{SSZ}-13$ with $\sim 2$ times higher Pd loading (Fig. S3). NO/Ru ratio for this sample is $\sim 2.7$, showing that there is another avenue of NO storage in addition to Ru-NO complex (discussed further in the text). Hydrothermal aging at $750{ }^{\circ} \mathrm{C}$ in $10 \% \mathrm{H}_{2} \mathrm{O} / \mathrm{O}_{2} / \mathrm{N}_{2}$ flow under simulated aging conditions does not lead to any appreciable loss of NOx storage of $0.5 \mathrm{wt} \% \mathrm{Ru} / \mathrm{ceria}$ (Fig. S4), consistent with high stability of $\mathrm{Ru}_{1} / \mathrm{CeO}_{2}$. Thus, $\mathrm{Ru}_{1} / \mathrm{CeO}_{2}$ represents an excellent $\mathrm{NO}$
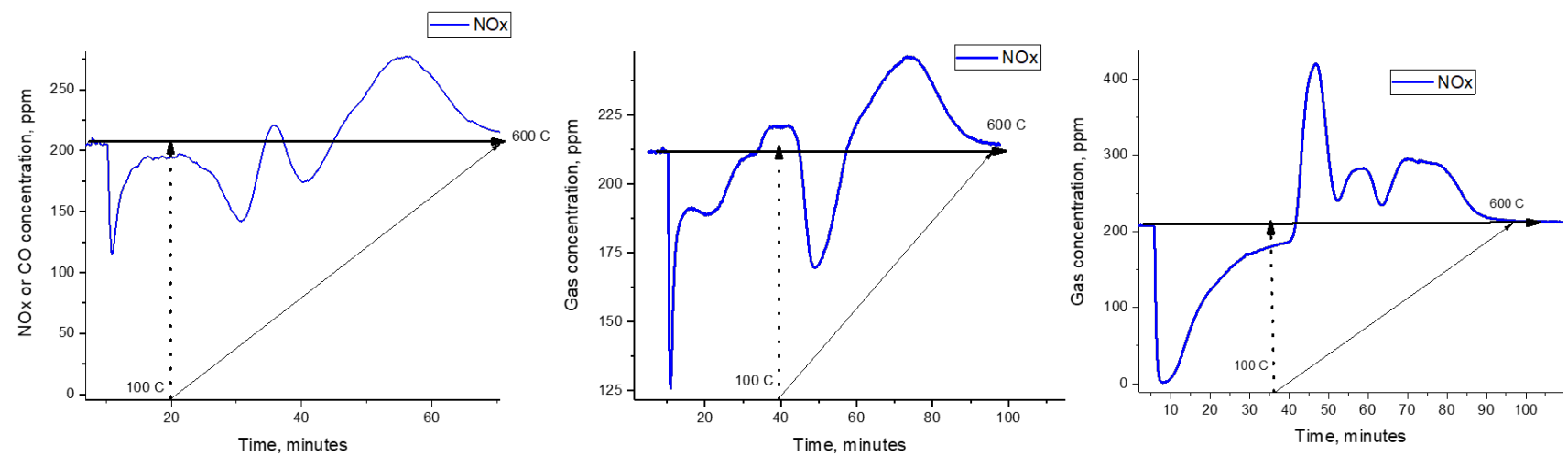

Figure 3. PNA Performance of A. $0.5 \mathrm{wt} \% \mathrm{Pd} / \mathrm{CeO}_{2} \mathrm{~B} .1 \mathrm{wt} \% \mathrm{Pt} / \mathrm{CeO} \mathrm{O}_{2} \mathrm{C} .0 .5 \mathrm{wt} \% \mathrm{Ru} / \mathrm{CeO}_{2}$. Catalyst mass $120 \mathrm{mg}$. Total flow rate 300 sscm/min. 200 ppm NOx, 13\% $\mathrm{O}_{2}, 3 \% \mathrm{H}_{2} \mathrm{O}, \sim 200$ (or $360 \mathrm{ppm} \mathrm{CO}$ ) balanced in $\mathrm{N}_{2}$. Adsorption experiments were performed at $100{ }^{\circ} \mathrm{C}$. Vertical dashed line indicates when the ramp $(10 \mathrm{~K} / \mathrm{min})$ was started.

specifically, Pd/zeolite formulations can store NOx at low temperatures $\left(\sim 100^{\circ} \mathrm{C}\right)$ and release them continuously $>180^{\circ} \mathrm{C}$ [7-26]. Pd is expensive and loadings of $1-2 \mathrm{wt} \%$ are required to oxidation catalyst (in the absence of $\mathrm{Pt} / \mathrm{Pd}$ metals) with remarkable NO storage capacity at cold-start temperatures. We wondered if we could decrease the loading of Ru even further,

Time (min)

$\begin{array}{lllllllllllllllll}0 & 5 & 10 & 15 & 20 & 25 & 30 & 35 & 40 & 45 & 50 & 55 & 60 & 65 & 70 & 75 & 80\end{array}$

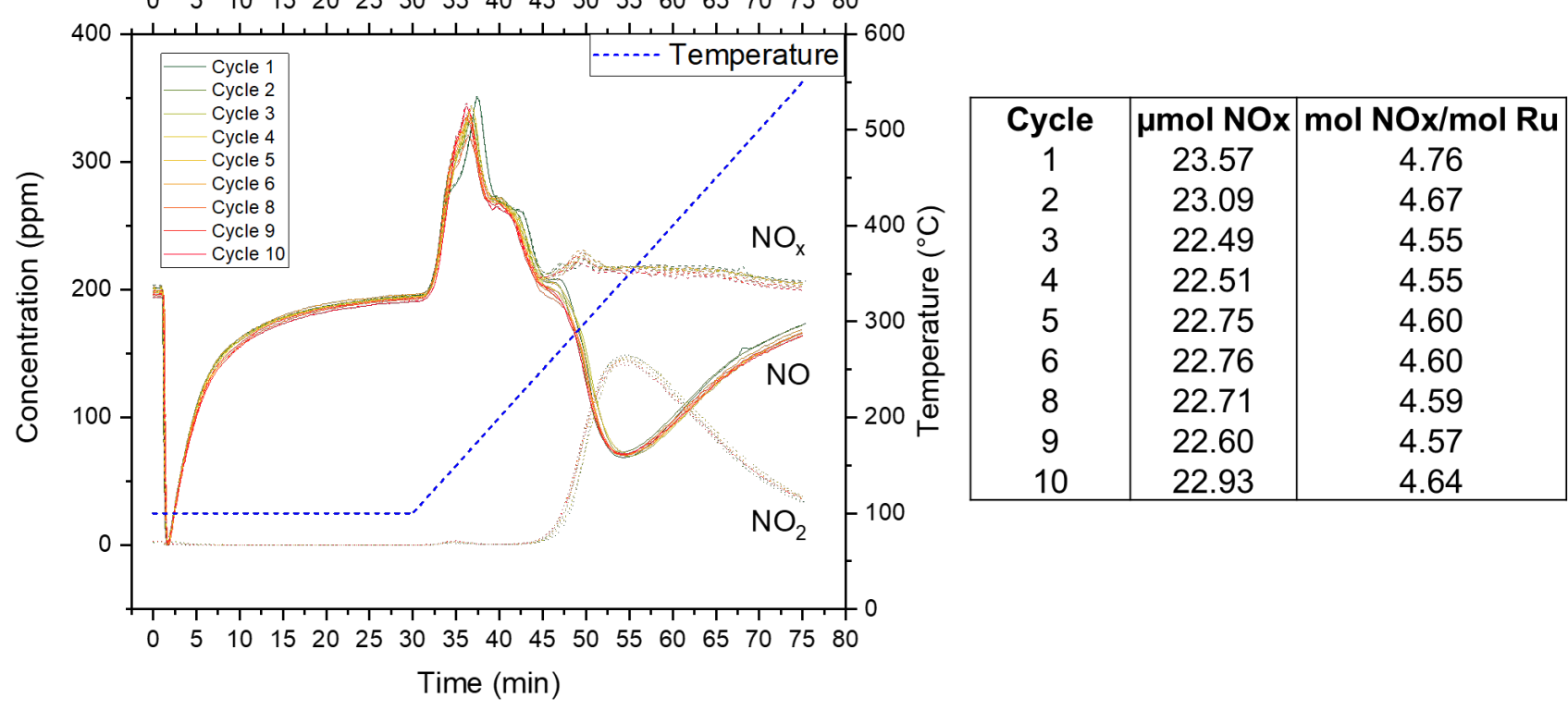

Figure 4 Performance and stability of $0.25 w t . \%$ Rul $/ \mathrm{CeO}_{2}$ during sequential cycles of low-temperature NOx adsorption and NO oxidation. Gas composition was 200 ppm of $\mathrm{NO}, 2000 \mathrm{ppm} \mathrm{CO}, 12 \% \mathrm{O}_{2}, \sim 3 \% \mathrm{H}_{2} \mathrm{O}$, balanced with $\mathrm{N}_{2} .120 \mathrm{mg}$ catalyst was used with GHSV 150 $\mathrm{L} / \mathrm{g} * \mathrm{hr}$. Adsorption experiments were performed at $100{ }^{\circ} \mathrm{C}$. The temperature ramp $\left(10{ }^{\circ} \mathrm{C} / \mathrm{min}\right)$ was started at a 30 minute mark; up to 550 ${ }^{\circ} \mathrm{C}$. NOx storage is shown per $120 \mathrm{mg}$ catalyst. On average the stored NOx amount is $\sim 190$ micromoles/gram.

achieve optimal NO adsorption. We, therefore, performed NO adsorption experiments on single-atom M/Ceria materials. Pt and while maintaining excellent NO adsorption properties and NO oxidation catalysis. We find that even at loading as low as 0.25 
wt $\% \mathrm{Ru}$, full $\mathrm{NO}$ adsorption still can be achieved under simulated cold-start conditions with excellent NO oxidation activity (Fig. 4). The sample shows stable NO adsorption and NO oxidation activity evaluated continuously over 10 cycles (Figs. 4, S5). CO oxidation remains completely stable as well (Fig. S6,S7). NO oxidation activity of $750{ }^{\circ} \mathrm{C}$ hydrothermally aged $0.25 \mathrm{wt} \%$ $\mathrm{Ru}_{1} / \mathrm{CeO}_{2}$ sample does not deteriorate and is comparable to the state-of-the-art industrial catalysts with $\sim 1-2 \mathrm{wt} \% \mathrm{Pd}$ (and Pt) (Fig. S21).

Ru-containing materials were studied for various catalytic processes $[51,52]$ in the past, yet no spectroscopic investigation of single-atom Ru materials [43-46] was reported. We, therefore, studied $\mathrm{CO}$ and $\mathrm{NO}$ adsorption with infra-red spectroscopy on 0.5 $w t \%$ Ru/ceria sample. $\mathrm{CO}$ adsorption (Figs. S8,S9) on the sample produces no metallic $\mathrm{CO}$ bands for $\mathrm{Ru}$ and reveals the presence of $\mathrm{Ru}(\mathrm{II})(\mathrm{CO})_{2}$ and $\mathrm{Ru}(\mathrm{II})(\mathrm{CO})_{3}$ complexes on the surface. Adsorption of NO produces a sharp band due to NO interaction with cationic $\mathrm{Ru}$ at $\sim 1,850 \mathrm{~cm}^{-1}$ (Fig. 5A). in modeling ceria surface and metal-ceria interactions using stateof-the-art DFT methods can provide a molecular level insight into the precise nature and location of metal ions on ceria surfaces [60-68]. Therefore, we modelled NO complexes of Ru cations adsorbed in different locations on ceria. Five different $\mathrm{RuO}(\mathrm{NO}) / \mathrm{Ce}_{21} \mathrm{O}_{42}$ complexes were modeled (Fig. 6, Table S2).

The most stable one, e-1O_NO, is obtained after adsorption of $\mathrm{NO}$ to the most stable $\mathrm{RuO} / \mathrm{Ce}_{21} \mathrm{O}_{42}$ complex, e-1O (notation of the structures is as in Ref. 63). In this complex, where Ru center is in octahedral coordination at the small $(100)$ facet of the $\mathrm{Ce}_{21} \mathrm{O}_{42}$ nanoparticle, $\mathrm{NO}$ donates an electron to a $\mathrm{Ce}^{4+}$ center, thus $\mathrm{NO}^{+}$ligand and a $\mathrm{Ce}^{3+}$ center are formed, while the formal charge of the Ru remains +2 . The other structures modelled are less stable by $1.42-2.91 \mathrm{eV}$, as the formal charge of $\mathrm{Ru}$ is +1 , since the unpaired electron is transferred from NO to the Ru center. In the structures a-10_NO and d-10_NO, Ru is in triangular planar coordination, interacting with two $\mathrm{O}$ centers and the $\mathrm{N}$ atom from $\mathrm{NO}$. The lowest $\mathrm{N}-\mathrm{O}$ vibrational frequencies were
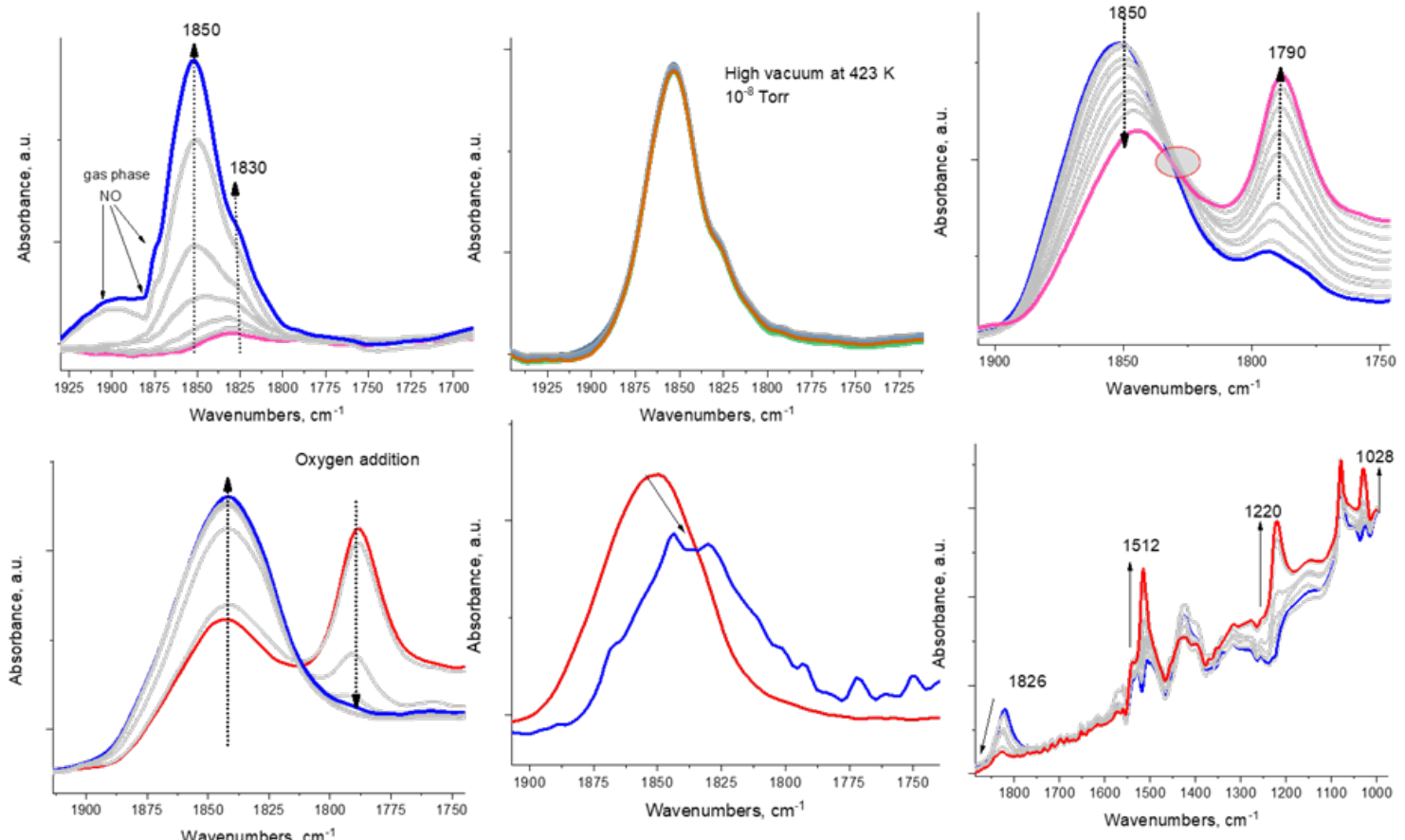

Figure 5. NO adsorption (0.5 Torr equilibrium pressure) at $298 \mathrm{~K}$ B. High vacuum after NO adsorption at $423 \mathrm{~K}$. Heating Ru-NO from 150 to $220{ }^{\circ} \mathrm{C}$ D. Introducing $\mathrm{O}_{2}$ at $220{ }^{\circ} \mathrm{C}$ after heating $\mathrm{Ru}$-NO E. Water adsorption on Ru-NO complex at $120{ }^{\circ} \mathrm{C} \mathrm{F} \mathrm{Ru-NO}$ heated in the presence of $\mathrm{O}_{2}+\mathrm{H}_{2} \mathrm{O}$ from 120 to $350{ }^{\circ} \mathrm{C}$ : Ru-NO diminishes and chelating nitrates form (bands at 1512, 1220 and $\left.1028 \mathrm{~cm}^{-1}\right)^{53}$.

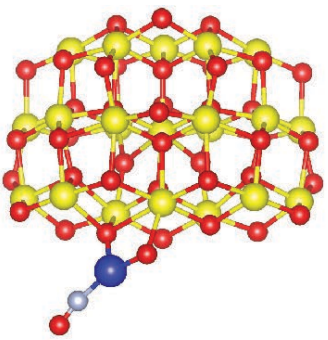

a-10_NO

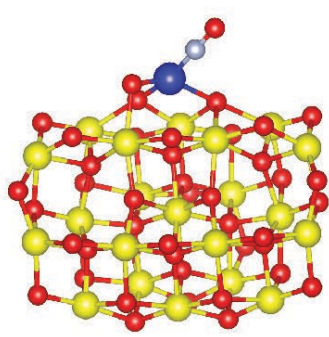

b-10_NO

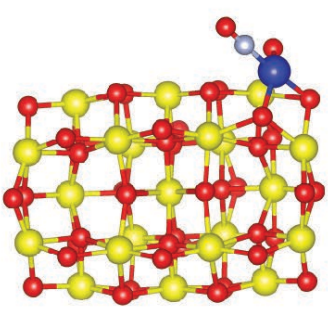

c-10_NO

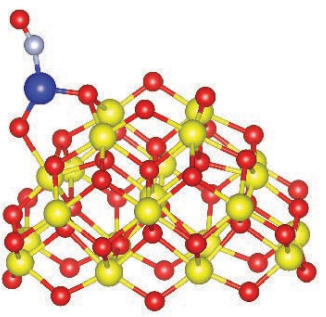

d-10_NO

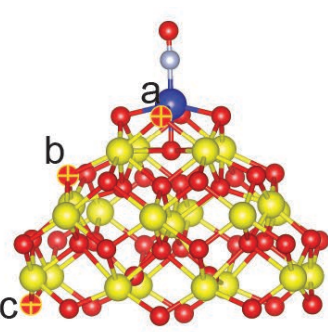

e-10_NO

Figure 6. Optimized $\mathrm{RuO}(\mathrm{NO}) / \mathrm{Ce}_{21} \mathrm{O}_{42}$ structures. In the case of e-1O NO complex with letters are denoted the O centers which are removed in order to obtain $\mathrm{RuO}(\mathrm{NO}) / \mathrm{Ce}_{21} \mathrm{O}_{41}$ structures. Color coding of atoms: Ce-yellow, $\mathrm{O}-\mathrm{red}$, Ru-dark blue, $N$-gray.

This clearly indicates the formation of a Ru-NO complex, stable even under high vacuum of $\sim 10^{-8}$ Torr (Fig. 5B). Recent advances calculated for these two structures, 1733 and $1763 \mathrm{~cm}^{-1}$. Ru is in square-planar coordination in the structures b-1O_NO and c- 
10_NO, which leads to higher N-O frequencies, 1799 and 1824 $\mathrm{cm}^{-1}$. The highest frequency was calculated for the most stable structure, e-10_NO, $1840 \mathrm{~cm}^{-1}$, where $\mathrm{Ru}$ is in octahedral coordination. This value is in excellent agreement with the experimental band at $1850 \mathrm{~cm}^{-1}$. Thus, FTIR with probe molecule NO combined with state-of-the-art DFT calculations precisely identify location of active isolated $\mathrm{Ru}^{+2}$ cations at the small (100) facets of ceria nanoparticles in octahedral configuration.

Upon temperature increase in the absence of oxygen (Fig. 5C) this band begins to decline with a new band growing at $\sim 1790$ $\mathrm{cm}^{-1}$ and a clear isosbestic point indicating the simple stoichiometric transition of $1 \mathrm{Ru}-\mathrm{NO}$ complex into the other. We suggest that this occurs due to oxygen-vacancy formation in the vicinity of the Ru atom: ON-Ru(vac)Ce. DFT calculations further corroborate this finding. To understand this process, we modeled structures with created $\mathrm{O}$ vacancy from $\mathrm{RuO}(\mathrm{NO}) / \mathrm{Ce}_{21} \mathrm{O}_{42}$ complexes (Table S2). The most stable structure is e10_NO_vac_a, where an O center was removed from the first coordination sphere of the $\mathrm{Ru}$ cation. The creation of such $\mathrm{O}$ vacancy led to decrease of the $\mathrm{N}-\mathrm{O}$ vibrational frequency from 1840 to $1788 \mathrm{~cm}^{-1}$ in excellent agreement with our experimental results. This is the first spectroscopic observation of the formation of an oxygen vacancy on ceria in the direct vicinity of the metal dopant next to ceria. Further, as soon as we add oxygen to this system, the vacancy is healed, and the NO adsorbed on Ru-OCe fully restores, further confirming our suggestion. This NO band is incredibly robust under high vacuum at $150{ }^{\circ} \mathrm{C}$ and does not completely disappear even at $350{ }^{\circ} \mathrm{C}$. In the presence of water, the NO band shifts to lower wavenumbers, the phenomenon that has been previously described for $\mathrm{Pd} / \mathrm{SSZ}-13$ and $\mathrm{Pd} / \mathrm{ZSM}-5$ and due to co-coordination of water and NO to the same Pd ion [4749]. We note, for example, that coordination of water to isoelectronic $\mathrm{Rh}(\mathrm{I})(\mathrm{CO})_{2}$ and $\mathrm{Rh}(\mathrm{I})(\mathrm{NO})_{2}$ complexes shifts the $\mathrm{CO}$ and $\mathrm{NO}$ bands to the lower wavenumbers. Simultaneously, in the presence of $\mathrm{O}_{2} / \mathrm{NO} / \mathrm{H}_{2} \mathrm{O}$ in the IR cell, infrared spectra emerge after running this under PNA relevant temperatures ( from 120 to $350{ }^{\circ} \mathrm{C}$ ), showing the decrease of ruthenium nitrosyl complex and increase in chelating nitrate bands on the ceria surface as shown by studies of Hadjiivanov, Vayssilov and co-workers [53]. Thus, ruthenium helps store $\mathrm{NO}$ both as a nitrosyl complex and allows $\mathrm{NO}_{x}$ to be stored on the ceria surface due to oxidation ability (as nitrites/nitrates) explaining high NO/Ru ratio which exceeds that of $\mathrm{NO} / \mathrm{Pd}$ ratio of $\mathrm{Pd}$ in zeolites.

We further investigated $\mathrm{NO}$ oxidation mechanism of $\mathrm{Ru}_{1} / \mathrm{CeO}_{2}$ using combined DRIFTS and mass spectrometry (Figs. S10-S15 show sequential in-situ DRIFTS and mass spectroscopy experiments that were performed).

We first performed NO adsorption in the DRIFTS flow-through cell, and the result agrees with static IR experiment: upon NO adsorption Ru-NO complex forms very fast and surface nitrites form more slowly. In the presence of oxygen, surface nitrites turn to surface nitrates at elevated temperatures. Only when the nitrates begin to decompose, mass-spec TPD with in-situ DRIFTS reveals that $\mathrm{NO}_{2}$ begins to form (this holds true for a few continuous IR/TPD MS cycles performed. We considered the NO oxidation on $\mathrm{RuO} / \mathrm{Ce}_{21} \mathrm{O}_{42}$ complexes (Table S3), considering the most stable positions for RuO species on both types of facets (100 and 111) on the $\mathrm{Ce}_{21} \mathrm{O}_{42}$ nanoparticle, e-1O and $\mathrm{c}-1 \mathrm{O}$ structures, respectively. This process includes four reaction steps: (1) oxidation of $\mathrm{Ru}$ species to $\mathrm{RuO}$; (2) adsorption of $\mathrm{NO}$ to $\mathrm{RuO} / \mathrm{Ce}_{21} \mathrm{O}_{42}$; (3) NO oxidation to $\mathrm{NO}_{2}$ on $\mathrm{Ru}$, as in the case of c-
10_NO complex the oxidation was considered from the additionally adsorbed in the first reaction step $O$ center, while in the e-10_NO complex the oxidation was done by an $\mathrm{O}$ center from the (100) facet; (4) $\mathrm{NO}_{2}$ desorption from $\mathrm{Ru} / \mathrm{Ce}_{21} \mathrm{O}_{42}$. The first two adsorption steps are strongly exothermic, while the oxidation and desorption are strongly endothermic. The ratelimiting step seems to be the $\mathrm{NO}$ oxidation, as the barriers are as high as 182 and $249 \mathrm{~kJ} / \mathrm{mol}$, respectively, on c-10 and e-10 sites. However, if all contributions to the enthalpy as well as the entropy are taken into account at temperature of $623 \mathrm{~K}$, the corresponding Gibbs free barriers become 154 and $200 \mathrm{~kJ} / \mathrm{mol}$. The former barrier seems to be operative at $623 \mathrm{~K}$, as the calculated kinetic constant is $1.58 \mathrm{~s}^{-1}$ (pre-exponential factor of the Eyring equation was taken to be 1) which corresponds to a half-life $\mathrm{T} 1 / 2$ of $\sim 0.44$ sec. The $\mathrm{NO}_{2}$ desorption is strongly endothermic, but when the entropy contribution is considered the endothermicity of the process is reduced by $\sim 150 \mathrm{~kJ} / \mathrm{mol}$, as in the case of $\mathrm{e}-10$ complex it becomes even exothermic. This corresponds very well with our DRIFTS/Mass-spec data showing that NO association with interfacial Ru-O-Ce oxygen as well as nitrate decomposition steps are the legitimate pathways of $\mathrm{NO}_{2}$ formation. The real rate constant at $623 \mathrm{~K}$ corresponds is $\sim 0.015 \mathrm{~s}^{-1}$ per Ru site $\left(\sim 54 \mathrm{hr}^{-1}\right)$. It agrees with the calculated TOF within acceptable error margin. Furthermore, it exceeds the TOF estimated for the most effective bimetallic and mono-metallic Pt and PtPd catalysts by at least 100 times. Therefore, Ru-O-Ce sites of single-atom Ru/ceria catalysts are very active for $\mathrm{NO}$ oxidation. However, the corresponding single-atom $\mathrm{Pt}(\mathrm{Pd})-\mathrm{O}-\mathrm{Ce}$ are poor $\mathrm{NO}$ (and $\mathrm{CO}$, for $\mathrm{Pt}[28-31,69-71])$ oxidation catalysts due to inability of $\mathrm{Pt}$ and $\mathrm{Pd}$ to form a stable Metal-NO bond that would ensure coverage of $\mathrm{NO}$ when the interfacial O removal from $\mathrm{M}-\mathrm{O}-\mathrm{Ce}$ sites becomes favourable, as well as a spill-over of NO species onto the ceria support as nitrates. Thus, $\mathrm{Ru}_{1} / \mathrm{CeO}_{2}$ stands out as the only ceriasupported material able to form thermally stable Ru-NO complexes.

To confirm the versatility of Ru/ceria materials for NOx related environmental catalysis, we now turn our attention to another challenging reaction for gasoline engines called NO reduction. TWC materials should perform catalytic removal of NOx in the presence of $\mathrm{CO}$ and water vapor under stoichiometric conditions [39-42]. We recently discovered that isolated $\mathrm{Rh}(\mathrm{I})$ ions on ceria can perform low temperature NO reduction by $\mathrm{CO}$ [42] effectively. We, therefore, wondered if $\mathrm{Ru}$ (which is $\sim 60$ times cheaper than $\mathrm{Rh}$ on the per-mass and per-molar basis) could also perform NO reduction by $\mathrm{CO}$ [69-71]. $0.5 \mathrm{wt} \% \mathrm{Ru}$ /ceria sample is excellent for $\mathrm{NO}$ reduction by $\mathrm{CO}$ under dry conditions. Addition of water to the stream, in fact, does not lead to activity deterioration (Fig. 7, Fig.S16): in this case ammonia production is observed in significant amounts, due to Ru/ceria being an excellent watergas-shift catalyst [42]. Decreasing Ru loading to $0.1 \mathrm{wt} \%$ also produces an active NO reduction catalyst, with excellent activity and full $\mathrm{NO}$ conversion $\sim 185{ }^{\circ} \mathrm{C}$. Thus, $\mathrm{Ru}_{1} / \mathrm{CeO}_{2}$ is an active catalyst for $\mathrm{NO}$ reduction by $\mathrm{CO}$ even at low Ru loading. TOF per $\mathrm{Ru}$ atoms $\sim 370 \mathrm{hr}^{-1}$ at $185{ }^{\circ} \mathrm{C}$.

Although the $\mathrm{Rh}_{1} / \mathrm{CeO}_{2}$ has been investigated using ex-situ infrared spectroscopy, the mechanism of $\mathrm{NO}$ reduction by $\mathrm{CO}$ for a single-atom $\mathrm{M}_{1} / \mathrm{CeO}_{2}$ catalysts remains unexplored by in-situ methods. The reason behind this is the lack of structurally uniform and well-defined catalysts whose spectroscopic signatures could be unambiguously determined during the interaction with $\mathrm{CO}$ and $\mathrm{NO}$ molecules. With well-defined $\mathrm{Ru}_{1} / \mathrm{CeO}_{2}$ we now have an 

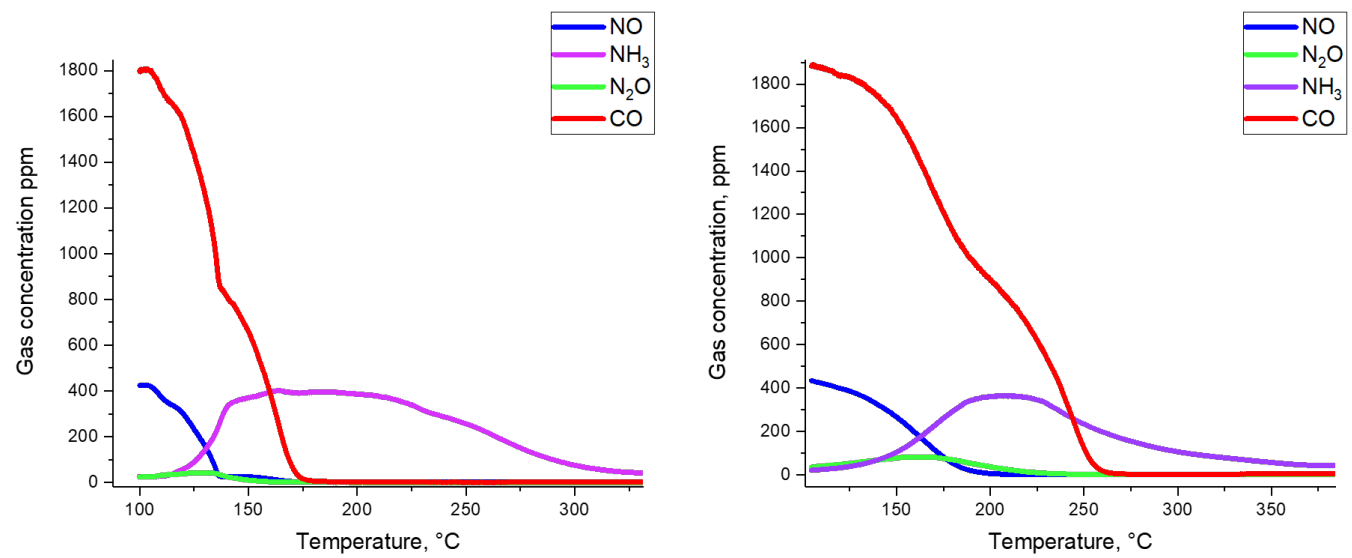

Figure 7. $\mathrm{NO}$ reduction performance of $0.5 \mathrm{wt} \% \mathrm{Ru} / \mathrm{CeO}_{2}$ (left graph) and $0.1 \mathrm{wt} \% \mathrm{Ru} / \mathrm{CeO}_{2}$ (Right graph). $120 \mathrm{mg}$ catalyst, $300 \mathrm{sscm} / \mathrm{min}$ total flow, GHSV $\sim 150 \mathrm{~L} / \mathrm{G}^{*} \mathrm{hr}, 470 \mathrm{ppm} \mathrm{NO}, 1850 \mathrm{ppm} \mathrm{CO} \sim 3 \% \mathrm{H}_{2} \mathrm{O}$ balnaced in $\mathrm{N}_{2}$. Performance of $0.5 \mathrm{wt} \% \mathrm{Ru} / \mathrm{CeO} \mathrm{O}_{2}$ sample under dry conditions is shown in Fig. S16.
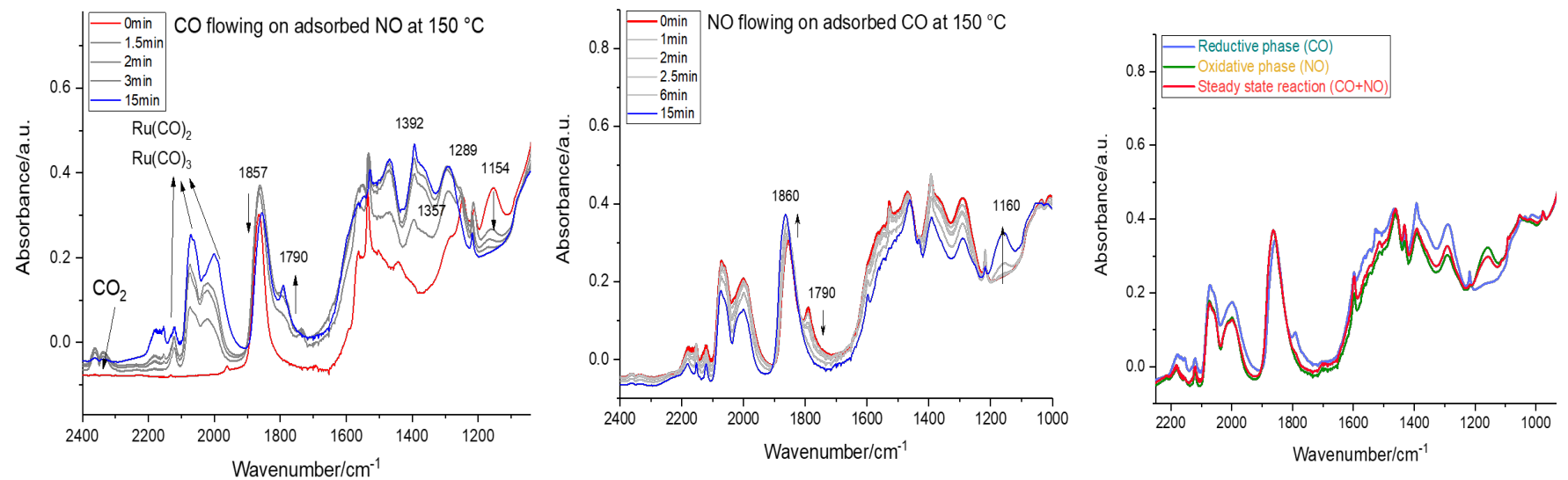

Figure 8. In-situ DRIFTS on $0.25 \mathrm{wt} \% \mathrm{Ru} / \mathrm{CeO}_{2}$. A. Exposure to CO (2,500 ppm) of NO-saturated sample (saturated with $500 \mathrm{ppm} \mathrm{NO}$ flow for 30 minutes, then purged with He at $150{ }^{\circ} \mathrm{C}$ before exposure to $\left.\mathrm{CO}\right) \mathrm{B}$. Subsequent exposure to NO flow after CO at $150{ }^{\circ} \mathrm{C}$. C. Comparison of the $\mathrm{Ru} / / \mathrm{CeO}_{2}$ during exposure to 2,500 ppm $\mathrm{CO}$ in the flow (,,reductive phase "), 500 ppm exposure to NO in the flow (,oxidative phase“), and (500 pppm NO + 2,5000 ppm CO) exposure in the flow (steady state reaction; in the DRIFTS cell NO conversion $\sim 30 \%$ under these conditions) at $150{ }^{\circ} \mathrm{C}$

opportunity to explore the individual steps of $\mathrm{NO}$ reduction by $\mathrm{CO}$ : in order to do so, we employed excitation-modulation DRIFTS approach in our infra-red measurements: in short, at a temperature where $(\mathrm{NO}+\mathrm{CO})$ conversion occurs $\left(150{ }^{\circ} \mathrm{C}\right)$, $\mathrm{NO}$ or $\mathrm{CO}$ pulses were applied to the system in antiphase for 3 consecutive cycles. The bands that appear/disappear in antiphase during these treatments indicate the appearance/consumption of the true catalytically active intermediates. Additionally, we performed in-situ DRIFTS with $(\mathrm{NO}+\mathrm{CO})$ flow at the same temperature (Figs 8, S17-S20).

During NO flow ( $\sim 500 \mathrm{ppm})$ at $150{ }^{\circ} \mathrm{C}$ Ru-NO band at $\sim 1860 \mathrm{~cm}$ ${ }^{1}$ appears, as well as nitrite bands associated with ceria at $\sim 1160$ $\mathrm{cm}^{-1}$. NO was then stopped, and CO flow started (2,500 ppm) (Fig. $8)$. Very dramatic changes were observed: nitrite band quickly decreased, simultaneously, Ce-O-Ru-NO band decreased with the concomitant evolution of the Ce-vacancy-Ru-NO band. Furthermore, the carbonate bands, easily attributable to poly- and mono-dentate carbonates, appeared (due to $\mathrm{CO}_{2}$ evolution; some of which re-adsorbs on the surface at $150{ }^{\circ} \mathrm{C}$ ). We then followed with NO treatment: NO treatment leads to the fast restoration of the Ru-NO band with the simultaneous healing of the oxygen vacancy; at the same time nitrite bands appears at $1160 \mathrm{~cm}^{-1}$.
Repetition of these NO-CO excitation-modulation cycles 3 times, allows to observe the phases that appear/disappear (respond dynamically during each cycle; Figs16-S20). The ones that are in anti-phase correspond to the active catalytic intermediates of the $\mathrm{NO}$ reduction by $\mathrm{CO}$ : indeed, during $\mathrm{CO}$ reduction: nitrites bands and $\mathrm{Ru}-\mathrm{NO}$ bands are consumed with the formation of the oxygen vacancy between $\mathrm{Ru}$ (vacancy)Ce and $\mathrm{CO}_{2}$ (carbonates). Treatment with $\mathrm{NO}$, leads to re-filling of the oxygen vacancy with oxygen from $\mathrm{NO}$ and restoration of nitrite bands. We previously [] suggested based on ex-situ measurements that for $\mathrm{Rh}_{1} / \mathrm{CeO}_{2} \mathrm{CO}$ reduces $\mathrm{Rh}(\mathrm{III})$ to $\mathrm{Rh}(\mathrm{I})$ (which we suggested to be the ratelimiting step of this reaction) with the following re-oxidation of $\mathrm{Rh}(\mathrm{I})$ with $\mathrm{NO}$ to $\mathrm{Rh}(\mathrm{III})$. Now, we show generally that we observe similar chemistry in-situ: but in this case, we prove the importance and direct participation of the oxygen vacancy between $\mathrm{Ru}$ and $\mathrm{Ce}$ in the catalysis: this vacancy is created by the process (1-5):

(1) $\mathrm{CO}-\mathrm{Ru}-\mathrm{O}-\mathrm{Ce} \rightarrow \mathrm{CO}_{2}+\mathrm{Ru}$ (vac) $\mathrm{Ce}$

(2) $\mathrm{Ru}(\mathrm{vac}) \mathrm{Ce}+2 \mathrm{NO} \rightarrow \mathrm{NO}-\mathrm{Ru}$ (vac) $\mathrm{Ce}-\mathrm{NO} \rightarrow$ $\mathrm{Ru}\left(\mathrm{N}_{2} \mathrm{O}_{2}\right) \mathrm{Ce} \rightarrow \mathrm{Ru}-\mathrm{O}-\mathrm{Ce}+\mathrm{N}_{2} \mathrm{O}$

(3) NO-Ru-O-Ce $\rightarrow \mathrm{Ru}$ (vac) $\mathrm{Ce}-\mathrm{NO}_{2}$

(4) $\mathrm{CO}+\mathrm{Ru}(\mathrm{vac}) \mathrm{Ce}-\mathrm{NO}_{2} \rightarrow \mathrm{CO}-\mathrm{Ru} \mathrm{Ce}-\mathrm{NO}_{2} \rightarrow \mathrm{CO}_{2}+\mathrm{Ru}$ $\mathrm{Ce}-\mathrm{NO}+\mathrm{NO} \rightarrow \mathrm{Ru}\left(\mathrm{N}_{2} \mathrm{O}_{2}\right) \mathrm{Ce} \rightarrow \mathrm{Ru}-\mathrm{O}-\mathrm{Ce}+\mathrm{N}_{2} \mathrm{O}$ 
(5) $\mathrm{Ru}(\mathrm{vac}) \mathrm{Ce}+\mathrm{N}_{2} \mathrm{O} \rightarrow \mathrm{O}=\mathrm{N}=\mathrm{N}-\mathrm{Ru}(\mathrm{vac}) \mathrm{Ce} \rightarrow \mathrm{N}_{2}+\mathrm{Ru}-\mathrm{O}-$ $\mathrm{Ce}$

The observation of the surface species during $(\mathrm{NO}+\mathrm{CO})$ flow over $\mathrm{Ru} /$ ceria sample in the DRIFTS cell $(\sim 30 \%$ NO conversion based on Mass-Spec data), and comparison with the states during NO and $\mathrm{CO}$ flows (Fig. 8), allows to conclude that during the reaction the surface remains mostly "oxidized". This is because the ratelimiting step is the removal of O between $\mathrm{Ru}-\mathrm{O}-\mathrm{Ce}$ by $\mathrm{CO}$ with the formation of $\mathrm{CO}_{2}$ : the subsequent steps (re-filling of the oxygen vacancy by $\mathrm{NO}$ ) occur much faster, and during $\mathrm{NO}+\mathrm{CO}$ flow we find basically mostly oxidized surface. However, the in-situ dynamic $\mathrm{NO} / \mathrm{CO}$ experiment allowed us to clarify the mechanism as well as slow/fast steps of $\mathrm{NO} / \mathrm{CO}$ reaction on atomically dispersed metal catalysts for the first time.

In summary, we discovered that $\mathrm{Ru}_{1} / \mathrm{CeO}_{2}$ catalysts show excellent performance for challenging $\mathrm{NO}_{x}$ pollutant abatement in both diesel and gasoline engines even at low metal loadings. We elucidated the location of active Ru(II) cations on the surface of ceria and provided molecular level understanding of the mechanism of NO oxidation, low-temperature NO storage and NO reduction by $\mathrm{CO}$ on these materials.

\section{Acknowledgements}

The research at PNNL was supported by the U.S. Department of Energy, Energy Efficiency and Renewable Energy, Vehicle Technology Office. Experiments were conducted in the Environmental Molecular Sciences Laboratory (EMSL), a national scientific user facility sponsored by the Department of Energy's Office of Biological and Environmental Research at Pacific Northwest National Laboratory (PNNL). PNNL is a multi-program national laboratory operated for the DOE by Battelle Memorial Institute under Contract DE-AC06-76RL01830. We acknowledge the support of CLEERS (Crosscut Lean Exhaust Emissions Reduction Simulations). CLEERS is an initiative funded by the U.S. Department of Energy (DOE) Vehicle Technologies Office to support the development of accurate tools for use in the design, calibration, and control of next generation engine/emissions control systems that maximize efficiency while complying with emissions regulations. HAA gratefully acknowledges the support by Bulgarian National Science Fund (project DN-19/2). GNV acknowledges the support of the project EXTREME, funded by the Bulgarian Ministry of Education and Science, D01$76 / 30.03 .2021$ through the programme "European Scientific Networks".

${ }^{*}$ Corresponding authors.

\section{Conflict of interest}

The authors filed for a patent.

(1) Royal College of Paediatrics and Child Health. Every breath we take-the lifelong impact of air pollution. London: Royal College of Paediatrics and Child Health, 2016.
(2) N. R. Jaegers, J. K. Lai, Y. He, E. Walter, D. A. Dixon, M. Vasiliu Y. Chen, C. M. Wang, M. Y. Hu, K. T. Mueller, I. E. Wachs, Y. Wang, J. Z. Hu, Angew. Chem., Int. Ed., 2019, 131, 12739-12746.

(3) Ja-Hun Kwak, Russell G Tonkyn, Do Heui Kim, János Szanyi, Charles HF Peden, J. Catal., 2010, 275, 187-190.

(4) I. Bull, A. Moini, G. Koermer, J. Patchett, W. Jaglowski, S. Roth, US Patent US20070134146A1, 2010.

(5) Zones, S.I. US Patent 4544 538, 1985

(6) T. Seiyama, T. Arakawa, T. Matsuda, N. Yamazoe, and Y. Takita, Chem. Lett., 781 (1975)

(7) Chen, H.-Y.; Collier, J. E.; Liu, D.; Mantarosie, L.; Durán- Martín, D.; Novák, V.; Rajaram, R. R.; Thompsett, D. Catal. Lett. 2016, 146 (9), 1706-1711.

(8) Khivantsev, K.; Jaegers, N. R.; Kovarik, L.; Hanson, J. C.; Tao, F. (Feng); Tang, Y.; Zhang, X.; Koleva, I. Z.; Aleksandrov, H. A.; Vayssilov, G. N.; Wang, Y.; Gao, F.; Szanyi, J. Angew. Chem. 2018, 130 (51), 16914-16919.

(9) Khivantsev, K.; Jaegers, N. R.; Kovarik, L.; Prodinger, S.; Derewinski, M. A.; Wang, Y.; Gao, F.; Szanyi, J. Appl. Catal. A. Gen. 2019, 569, 141-148.

(10) Khivantsev, K.; Jaegers, N. R.; Koleva, I. Z.; Aleksandrov, H. A.; Kovarik, L.; Engelhard, M.; Gao, F.; Wang, Y.; Vayssilov, G. N.; Szanyi, J. J. Phys. Chem. C 2020, 124 (1), 309-321.

(11) Khivantsev, K.; Gao, F.; Kovarik, L.; Wang, Y.; Szanyi, J. J. Phys. Chem. C 2018, 122 (20), 10820-10827.

(12) Moliner, M.; Corma, A. React. Chem. Eng. 2019, 4 (2), 223-234

(13) Khivantsev, K.; Jaegers, N. R.; Kovarik, L.; Hu, J. Z.; Gao, F.; Wang, Y.; Szanyi, J. Emiss. Control Sci. Technol. 2019. DOI: 10.1007/s40825-019-00139-w

(14) E. Bello, V. J. Margarit, E. M. Gallego, F. Schuetze, C. Hengst , A Corma, M. Moliner, Microporous and Mesoporous Materials 302 (2020) 110222

(15) K. Khivantsev, N. R. Jaegers, L. Kovarik, M. Wang, J. Z. Hu, Y. Wang, M. Derewinski, J. Szanyi, Chemrxiv 2020 DOI: 10.26434/chemrxiv.11821347

(16) Rajaram, R. R., Chen, H.-Y., Liu, D., US Patent US20150158019A1, 2015

(17) Y. Ji, S. Bai and M. Crocker, Appl. Catal., B, 2015, 107-171 , 283292.

(18) Ji, Y.; Xu, D.; Bai, S.; Graham, U.; Crocker, M.; Chen, B.; Shi, C.; Harris, D.; Scapens, D.; Darab, J. Ind. Eng. Chem. Res. 2017, 56, 111-125.

(19) K Khivantsev, J Szanyi, NR Jaegers, L Kovarik, F Gao, Y Wang, US Patent App. 16/546,641

(20) L. Castoldi, R. Matarrese, S. Morandi, P. Ticali, Luca Lietti, Catal. Today 2020 doi.org/10.1016/j.cattod.2020.02.019

(21) A. Porta, T. Pellegrinelli, L. Castoldi, R. Matarrese, S. Morandi, S. Dzwigaj, L. Lietti, Top. Catal. 61 (2018) 2021-2034.

(22) Y. Ji, S. Bai, D. Xu, D. Qian, Z. Wu, Y. Song, R. Pace, M. Crocker, K. Wilson, A. Lee, D. Harris, D. Scapens, App. Cat. B. 2019 doi: https://doi.org/10.1016/j.apcatb.2019.118499

(23) Ryou, Y. S.; Lee, J.; Cho, S. J.; Lee, H.; Kim, C. H.; Kim, D. Appl. Catal. B Environ. 2017, 212, 140-149.

(24) Ryou, Y. S.; Lee, J.; Lee, H.; Kim, C. H.; Kim, D. H., Catal. Today 2019, 320, 175-180.

(25) Lee, J.; Ryou, Y.; Hwang, S.; Kim, Y.; Cho, S. J.; Lee, H.; Kim, C. H.; Kim, D. H., Catal. Sci. Technol. 2019, 9 (1), 163-173.

(26) Kim, Y.; Hwang, S.; Lee, J.; Ryou, Y. S.; Lee, H.; Kim, C. H.; Kim, D. H. Emiss. Control Sci. Technol. 2019, 5 (2), 172-182.

(27) K. Khivantsev, X. Wei, L. Kovarik, N. R. Jaegers, E. D. Walter, P. Tran, Y. Wang, J. Szanyi, Chemrxiv 2020 DOI: 10.26434/chemrxiv.12385577

(28) Pereira-Hernandez, X. I.; DelaRiva, A.; Kunwar, D.; Xiong, H.; Sudduth, B.; Engelhard, M.; Kovarik, L.; Murayev, V.; Hensen, E.; Wang, Y.; Datye, A. K. Nat. Commun. 2019, DOI: 10.1038/s41467019-09308-5

(29) Datye, A.; Wang, Y. Natl. Sci. Rev. 2018, 5, 630-632. 
(30) Jones, J.; Xiong, H.; DeLaRiva, A. T.; Peterson, E. J.; Pham, H.; Challa, S. R.; Qi, G.; Oh, S.; Wiebenga, M. H.; Pereira Hernandez, X. I.; Wang, Y.; Datye, A. K. Science 2016, 353, 150-154.

(31) Nie, L.; Mei, D.; Xiong, H.; Peng, B.; Ren, Z.; Hernandez, X. I. P.; DeLaRiva, A.; Wang, M.; Engelhard, M. H.; Kovarik, L.; Datye, A K.; Wang, Y., Science 2017, 358, 1419.

(32) Twigg, M.V., Haren Gandhi 1941-2010: Contributions to the Development and Implementation of Catalytic Emissions Control Systems. Platinum Metals Review, 2011. 55(1): p. 43-53.

(33) Warlimont, H.; W.E. Martienssen, eds. Springer Handbook of Condensed Matter and Materials Data. 2006.

(34) M. Koebel, M. Elsener, M. Kleemann, Catal. Today 59,335 (2000).

(35) N. Takahashi et al., Catal. Today 27, 63 (1996)

(36) M. Koebel, G. Madia, M. Elsener, Catal. Today 73, 239 (2002).

(37) P. Bourges, S. Lunati, G. Mabilon, Catalysis And Automotive Pollution Control IV 116, 213 (1998)

(38) C. H. Kim, G. Qi, K. Dahlberg, W. Li, Science, 327, pp. 1624-1627.

(39) Harrison, B, Diwell, AF, Hallett, C. Promoting platinum metals by ceria. Platinum Metals Rev1988; 32: 73-83.

(40) Taylor, K. Catal. Rev.: Sci. Eng. 1993, 35 (4), 457-481.

(41) Granger, P.; Parvulescu, V. I. Chem. Rev. 2011, 111.

(42) K. Khivantsev, C. Vargas, J. Tian, L. Kovarik, N. R. Jaegers, J. Szanyi, Y. Wang, Angewandte Chemie 133 (1), 395-402

(43) Hadjiivanov, K.; Lavalley, J.-C.; Lamotte, J.; Mauge, F.; SaintJust, J.; Che, M. J. Catal. 1998, 176, 415.

(44) H. Miessner, J. Am. Chem. Soc. 1994, 116, 11522-11530.

(45) Miessner, H.; Richter, K. J. Mol. Catal. A-Chem. 1999, 146, 107115.

(46) Chen, H.-Y.; Collier, J. E.; Liu, D.; Mantarosie, L.; Durán- Martín, D.; Novák, V.; Rajaram, R. R.; Thompsett, D. Catal. Lett. 2016, 146 (9), 1706-1711.

(47) Chakarova K, Ivanova E, Hadjiivanov K, Klissurski D, Knozinger H (2004) Phys Chem Chem Phys 6:3702

(48) J.Lee, J. Kim, Y. Kim, S. Hwang, H. Lee, C. H. Kim, D. H. Kim, Appl. Catal. B, 2020, 277, 119190

(49) K. Khivantsev, PhD Thesis, University of South Carolina, 2015

(50) A.R. Derk, G.M. Moore, S. Sharma, E.W. McFarland, H Metiu, Top Catal 57, 118-124 (2014). https://doi.org/10.1007/s11244-013 0167-2A

(51) D. Chester, A. R. Derk, S. Sharma, H. Metiu, E. W. McFarland, Catal. Sci. Technol., 2015,5, 1783-1791

(52) M. Y. Mihaylov, V. R. Zdravkova, E. Z. Ivanova, H.A. Aleksandrov, P.St. Petkov, G.N. Vayssilov, K.I. Hadjiivanov, Journal of Catalysis 2020 https://doi.org/j.jcat.2020.06.015

(53) J. P. Perdew, J. A. Chevary, S. H. Vosko, K. A. Jackson, M. R. Pederson, D. J. Singh and C. Fiolhais, Phys. Rev. B, 1992, 46, 6671-6687;

(54) G. Kresse and J. Hafner, Phys. Rev. B, 1993, 47, 558-561.

(55) Version VASP.4.9; http://cms.mpi.univie.ac.at/vasp/

(56) G. Kresse and D. Joubert, Phys. Rev. B, 1999, 59, 1758-1775

(57) V. I. Anisimov, F. Aryasetiawan and A. I. Lichtenstein, J. Phys. Condens. Matter, 1997, 9, 767-808.

(58) S. L. Dudarev, G. A. Botton, S. Y. Savrasov, C. J. Humphreys and A. P. Sutton, Phys. Rev. B, 1998, 57, 1505-1509.

(59) C. Loschen, J. Carrasco, K. M. Neyman and F. Illas, Phys. Rev. B, 2007, 75, 035115

(60) A. Migani, G. N. Vayssilov, S. T. Bromley, F. Illas and K. M. Neyman, Chem. Commun., 2010, 46, 5936-5938.

(61) A. Migani, G. N. Vayssilov, S. T. Bromley, F. Illas and K. M. Neyman, J. Mater. Chem., 2010, 20, 10535-10546.

(62) H. A. Aleksandrov, K. M. Neyman, and G. N. Vayssilov, Physica Chemistry Chemical Physics, 2015, 17, 14551-14560.

(63) H.A. Aleksandrov, K.M. Neyman, K.I. Hadjiivanov, G.N. Vayssilov, Physical Chemistry Chemical Physics, 201618 (32), 22108-22121

(64) I.Z. Koleva, H.A. Aleksandrov, G.N. Vayssilov, Catalysis Science \& Technology, 20177 (3), 734-742

(65) G. N. Vayssilov, Y. Lykhach, A. Migani, T. Staudt, G. P. Petrova, N Tsud, T. Skála, A. Bruix, F. Illas, K. C. Prince, K. M. Neyman, J. Libuda, Nature materials, 2011, 10 (4), 310-315.
(66) M. Capdevila-Cortada, N. López, Nature Materials 16 328-334 (2017)

(67) M. Capdevila-Cortada, G. Vilé, D. Teschner, J. Pérez-Ramírez, N López, Applied Catalysis B: Environmental 197 299-312 (2015).

(68) N. Daelman, M. Capdevila-Cortada, N. López, Nature Materials 18 1215-1221 (2019)

(69) H Jeong, G Lee, BS Kim, J Bae, JW Han, H Lee, 2Journal of the American Chemical Society 140 (30), 9558-9565 (2018)

(70) H Jeong, J Bae, JW Han, H Lee, ACS Catalysis 7 (10), 7097-7105 (2019)

(71) H Jeong, O Kwon, BS Kim, J Bae, S Shin, HE Kim, J Kim, H Lee, Nature Catalysis 3 (4), 368-375 (2020) 


\section{Identification of single Ru(II) ions on ceria as a highly active catalyst for abatement of NOx pollutants}

Konstantin Khivantsev,${ }^{a *} \dagger$ Nicholas R. Jaegers, ${ }^{a} \dagger$ Hristiyan A. Aleksandrov, ${ }^{b} \dagger^{*}$ Inhak Song, ${ }^{a}$ Xavier Isidro Pereira-Hernandez, ${ }^{a}$ Jinshu Tian ${ }^{\mathrm{a}}$, Libor Kovarik, ${ }^{\mathrm{a}}$ Georgi N. Vayssilov, ${ }^{\mathrm{b}}$ Yong Wang ${ }^{\mathrm{a}, \mathrm{c}^{*}}$ and János Szanyi ${ }^{a}{ }^{*}$

\section{Supplementary Information}

\section{Materials and Methods}

Cerium nitrate hexahydrate was purchased from Sigma with purity of $99.999 \%$. Ceria nanoparticles were prepared from it by heating in a regular muffle furnace under static conditions at $600{ }^{\circ} \mathrm{C}$ for 5 hours. Ruthenium nitrosyl nitrate solution was purchased from Sigma and used as is. To prepare the loadings of Ru on ceria of $0.1,0.25$ and $0.5 \mathrm{wt} \%$, the desired amount of $\mathrm{Ru}$ precursor solution was dissolved in the minimum amount of water (total volume approximately equivalent to the pore of volume ceria) and added with a micropipette to the desired amount of ceria while continuously stirring with the spatula to ensure uniformity. The obtained wetted powder was dried under $\mathrm{N}_{2}$ flow at $80{ }^{\circ} \mathrm{C}$, and then calcined at $800{ }^{\circ} \mathrm{C}$ for 1 hour in a regular muffle furnace with a ramp rate of $5{ }^{\circ} \mathrm{C} / \mathrm{min}$. The as-prepared $\mathrm{Ru} / \mathrm{Ceria}$ powders were pressed, crushed and sieved to 60-80 mesh, and subsequently used as catalysts. Samples with 0.5 and $1 \mathrm{wt} \%$ loading of $\mathrm{Pd}$ and $\mathrm{Pt}$, respectively, were prepared in a way identical to the $\mathrm{Ru} /$ ceria sample. Pd and Pt tetramine nitrate salts (Sigma) were used as Pd and Pt precursors.

$\mathrm{Na}$ /SSZ-13 zeolite with Si/Al $~ 6$ was hydrothermally synthesized using the following recipe: $0.8 \mathrm{~g}$ of $\mathrm{NaOH}$ (Sigma Aldrich, $\geq 99 \%$ ) was dissolved in $50 \mathrm{ml}$ of deionized water. Then, $17 \mathrm{~g}$ of TMAda-OH (Sachem Inc., 25\% N,N,N-trimethyl-1-adamantyl ammonium hydroxide) was added as structure directing agent. Consequently, $1.5 \mathrm{~g}$ of $\mathrm{Al}(\mathrm{OH})_{3}$ (Sigma Aldrich, $\sim 54 \% \mathrm{Al}_{2} \mathrm{O}_{3}$ ) was slowly added to the solution and stirred at $400 \mathrm{rpm}$ until it was completely dissolved. Afterwards, $20.0 \mathrm{~g}$ of LUDOX HS-30 colloidal silica (Sigma Aldrich, 30 wt\% suspension in $\mathrm{H}_{2} \mathrm{O}$ ) was added slowly to the solution until a uniform white gel was formed. The obtained gel was sealed in a $125 \mathrm{~mL}$ Teflon-lined stainless steel autoclave containing a magnetic stir bar. Hydrothermal synthesis was carried out at $160^{\circ} \mathrm{C}$ under continuous gel stirring at $400 \mathrm{rpm}$ for 4 days. After synthesis, the zeolite cake was separated from the suspension by centrifugation and washed thoroughly with deionized water. It was then dried at $80^{\circ} \mathrm{C}$ under $\mathrm{N}_{2}$ flow overnight and calcined in air at $550^{\circ} \mathrm{C}$ for $5 \mathrm{~h}$ in order to remove the SDA. $\mathrm{NH}_{4} / \mathrm{SSZ}-13$ was obtained by ion exchange 
of the as-prepared $\mathrm{Na} / \mathrm{SSZ}-13$ zeolite with $0.5 \mathrm{M} \mathrm{NH}_{4} \mathrm{NO}_{3}$ solution at $80^{\circ} \mathrm{C}$ for $5 \mathrm{~h}$. The process was repeated three times.

$\mathrm{Pd} /$ Zeolite powders with desired loading of $\mathrm{Pd}(1 \mathrm{wt} \%)$ was obtained via modified incipient wetness impregnation method, described by us earlier, with $\mathrm{Pd}(\mathrm{II})$ tetramine nitrate solution (10 wt \%, Sigma) and $\mathrm{NH}_{4}$-forms of zeolites. Benefits of using palladium (II) tetra-amine nitrate precursor versus palladium nitrate as well as $\mathrm{NH}_{4}$-forms of zeolite were previously described in detail $[8,11]$. They were subsequently dried at $80^{\circ} \mathrm{C}$ and subsequently calcined at $650^{\circ} \mathrm{C}$ in static air. More specifically a minimum amount of the $\mathrm{Pd}(\mathrm{II})$ precursor solution was added to zeolite in the amount approximately equivalent to the total pore volume of the zeolite. The thick paste was mixed for 30 minutes, followed by calcination in air at $650^{\circ} \mathrm{C}$ for $5 \mathrm{~h}$ (ramping rate $2^{\circ} \mathrm{C} / \mathrm{min}$ ).

Diesel oxidation catalyst used for comparison of NO oxidation performance with Ru/Ceria catalyst was the commercial state-of-the-art diesel oxidation catalyst scraped off the real diesel aftertreatment system ("Cummins") fully compliant with the latest EPA Tier 4 Final and EU Stage IV emission standards. The powder was crushed and sieved to 60-80 mesh prior to testing.

Hydrothermal aging (HTA) was performed at $750^{\circ} \mathrm{C}$ for 10 hours in a flow reactor with GHSV $150 \mathrm{~L} / \mathrm{g}^{*} \mathrm{hr}$. The gas mix, used for HTA, containing air and 10\% $\mathrm{H}_{2} \mathrm{O}$ in air.

$(\mathrm{NO}+\mathrm{CO})$ catalytic experiments were conducted in a plug-flow reactor system with powder samples (120 mg, 60-80 mesh) loaded in a quartz tube, using a synthetic gas mixture containing 460 ppm of $\mathrm{NO}$ and 1,750 ppm CO balanced with $\mathrm{N}_{2}$ at a flow rate of $310 \mathrm{sccm}$ (corresponding to GHSV $150 \mathrm{~L} / \mathrm{g}^{*} \mathrm{hr}$ ). Wet experiments were performed in the presence of $2.6 \%$ water vapor. All the gas lines were heated to over $100{ }^{\circ} \mathrm{C}$. Concentrations of reactants and products were measured by an online MKS MultiGas 2030 FTIR gas analyzer with a gas cell maintained at $191^{\circ} \mathrm{C}$. Two four-way valves were used for gas switching between the reactor and the bypass. Heating and cooling rates were $2 \mathrm{~K} / \mathrm{min}$.

Standard NOx adsorption tests were conducted in a plug-flow reactor system with powder samples (120 mg, 60-80 mesh) loaded in a quartz tube, using a synthetic gas mixture that contained $\sim 200$ ppm of NOx, CO (360 ppm), $14 \% \mathrm{O}_{2}, 3 \% \mathrm{H}_{2} \mathrm{O}$ balanced with $\mathrm{N}_{2}$ at a flow rate of $300 \mathrm{sccm}$ at $100{ }^{\circ} \mathrm{C}$. All the gas lines were heated to over $100^{\circ} \mathrm{C}$. Concentrations of reactants and products were measured by an online MKS MultiGas 2030 FTIR gas analyzer with a gas cell maintained at $191^{\circ} \mathrm{C}$. GHSV for all the adsorption/desorption experiments was $150 \mathrm{~L} / \mathrm{g}^{*} \mathrm{hr}$. Heating rate was $10 \mathrm{~K} / \mathrm{min}$.

NO oxidation experiments were conducted in the same plug-flow reactor system in the presence and absence of water. $120 \mathrm{mg}$ of desired catalyst were loaded, and the experiments were performed in the presence of $460 \mathrm{ppm} \mathrm{NO}, 3 \%$ water, $13 \% \mathrm{O}_{2}$ balanced with nitrogen. Heating and cooling rates were $2 \mathrm{~K} / \mathrm{min}$. 
BET surface areas were conducted on a Micromeritics ASAP-2000 instrument with Ar as the adsorbate. Prior to analysis, the samples were dehydrated under vacuum for 3 hours at $250{ }^{\circ} \mathrm{C}$.

HAADF-STEM analysis was performed with an FEI Titan 80-300 microscope operated at $300 \mathrm{kV}$. The instrument is equipped with a CEOS $\mathrm{GmbH}$ double-hexapole aberration corrector for the probe-forming lens which allows for imaging with $0.1 \mathrm{~nm}$ resolution in scanning transmission electron microscopy mode (STEM). The images were acquired with a high angle annular dark field (HAADF) detector with inner collection angle set to 52 mrad. The powder samples were loaded into the sample holder. The images were collected in various projections and imaged immediately to minimize beam damage during the experiment.

DRIFTS experiments recorded on a Nicolet iS50R FTIR spectrometer at $4 \mathrm{~cm}^{-1}$ resolution. The spectrometer was connected to the mass-spectrometer for simultaneous monitoring of the gas effluent. The catalyst powder was packed into the DRIFTS cell and transferred to the cell where it was connected to the gas manifold and exposed to the flow of gases $\left(\mathrm{NO}, \mathrm{O}_{2}, \mathrm{CO}, \mathrm{He}\right.$ in desired concentrations - all of the gases ultra-high purity grade). Spectra were referenced to $\mathrm{KBr}$ background (at different temperatures) and 64 scans were averaged in each spectrum. Flow rates were $\sim 150 \mathrm{~L} / \mathrm{g}^{*} \mathrm{hr}$.

The in situ transmission IR experiments were conducted in a home-built cell housed in the sample compartment of a Bruker Vertex 80 spectrometer, equipped with an MCT detector and operated at $4 \mathrm{~cm}^{-1}$ resolution. The powder sample was pressed onto a tungsten mesh which, in turn, was mounted onto a copper heating assembly attached to a ceramic feedthrough. The sample could be resistively heated, and the sample temperature was monitored by a thermocouple spot welded onto the top center of the $\mathrm{W}$ grid. The cold finger on the glass bulb containing $\mathrm{CO}$ was cooled with liquid nitrogen to eliminate any contamination originating from metal carbonyls, while NO was cleaned with multiple freeze-pump-thaw cycles. Prior to spectrum collection, a background with the sample in the IR beam was collected. Each spectrum reported is obtained by averaging 64 scans.

\section{Computational method and models}

The calculations are performed with periodic plane-wave density functional method using a GGA exchange-correlation functional PW91, ${ }^{1}$ as implemented in VASP code. ${ }^{2-4}$ An on-site Coulombic correction $\left(U_{\text {eff }}=U-J\right)^{5,6}$ is applied within the GGA+U scheme to all Ce atoms to obtain a localized description of $\mathrm{Ce} 4 \mathrm{f}$-electrons in reduced $\mathrm{Ce}^{3+}$ ions. In line with previous studies $^{7,8}$ the $U_{\text {eff }}$ value of $4.0 \mathrm{eV}$ is used. A plane-wave basis with a $415 \mathrm{eV}$ cut-off for the kinetic energy and projector-augmented wave ${ }^{4}$ description of core-valence electron interactions are employed. Our model ceria nanoparticle $\mathrm{Ce}_{21} \mathrm{O}_{42}$ has a diameter of about $1 \mathrm{~nm}$.7,8 A cubic 2.0 $\times 2.0 \times 2.0 \mathrm{~nm}$ unit cell is employed. Thus, each nanoparticle is separated from its periodically 
repeated images in the neighboring unit cells in the three Cartesian directions by at least 0.9 $\mathrm{nm}$ to minimize interactions between the nanoparticles. Г-point calculations are performed. Single-point total energy convergence tolerance at the self-consistency is set to $10^{-6} \mathrm{eV}$ and structure optimizations continued until the maximum forces acting on each atom were less than $0.02 \mathrm{eV} / \AA \AA$. Where appropriate, spin-polarized calculations were performed in order to account for the reducibility of the $\mathrm{Ce}^{4+}$ ions.

The reported binding energies $(\mathrm{BE})$ of the adsorbed $\mathrm{NO}$ on the Ru/ceria substrates are calculated as $B E=-E_{a d}-E_{s u b}+E_{a d / s u b}$, where $E_{a d}$ is the total energy of the NO adsorbate in the gas phase, $E_{\text {sub }}$ is the total energy of the corresponding Ru/ceria substrate system, and $E_{a d / s u b}$ is the total energy of the substrate interacting with the NO adsorbate. With the above definition, negative values of BE imply favorable exothermic adsorption interaction.

Oxygen vacancy formation energies $\mathrm{E}_{\mathrm{vac}}$ of the $\mathrm{RuO}(\mathrm{NO}) / \mathrm{Ce}_{21} \mathrm{O}_{42}$ complexes were calculated with respect to a half of the triplet-state energy of a free $\mathrm{O}_{2}$ molecule $\mathrm{E}\left(\mathrm{O}_{2}\right)$ :

$$
\mathrm{E}_{\mathrm{vac}}=\mathrm{E}\left(\mathrm{RuO}(\mathrm{NO}) / \mathrm{Ce}_{21} \mathrm{O}_{41}\right)+1 / 2 \mathrm{E}\left(\mathrm{O}_{2}\right)-\mathrm{E}\left(\mathrm{RuO}(\mathrm{NO}) / \mathrm{Ce}_{21} \mathrm{O}_{42}\right)
$$

From the calculated energy values and vibrational frequencies we obtained the Gibbs free energies for the various ceria-containing models:

$$
\Delta G\left(\mathrm{RuO}_{x}(\mathrm{NO})_{\mathrm{m}} / \mathrm{Ce}_{21} \mathrm{O}_{42-\mathrm{Y}}\right)=\Delta H\left(\mathrm{RuOx}(\mathrm{NO})_{\mathrm{m}} / \mathrm{Ce}_{21} \mathrm{O}_{42-\mathrm{Y}}\right)-T \Delta S\left(\mathrm{RuOX}(\mathrm{NO}) \mathrm{m} / \mathrm{Ce}_{21} \mathrm{O}_{42-\mathrm{Y}}\right),
$$
where $\mathrm{X}=0$ or $1, \mathrm{~m}=0$ or $1, \mathrm{Y}=0$ or 1 .

The enthalpy values, $\Delta H\left(\mathrm{RuO} \times(\mathrm{NO})_{\mathrm{m}} / \mathrm{Ce}_{21} \mathrm{O}_{42-\mathrm{Y}}\right)$, were obtained from the electronic energies $\mathrm{E}_{\mathrm{el}}\left(\mathrm{RuOx}(\mathrm{NO})_{\mathrm{m}} / \mathrm{Ce}_{21} \mathrm{O}_{42-\mathrm{Y}}\right)$ corrected for the internal vibrational energy $\mathrm{E}_{\mathrm{v}}{ }^{9}$ and zeropoint vibrational energy (ZPE) derived from all vibrational frequencies:

$$
H=E_{e l}+E_{v}+Z P E .
$$

In the calculation of the entropy values of the $\mathrm{RuOx}(\mathrm{NO})_{\mathrm{m}} / \mathrm{Ce}_{21} \mathrm{O}_{42-\mathrm{Y}}$ structures only the electronic $\left(S_{e l}\right)$ and vibrational $\left(S_{v}\right)$ degrees of freedom were taken into account. ${ }^{10,11}$ For the NO, $\mathrm{NO}_{2}$, and $\mathrm{O}_{2}$ molecules in the gas phase translational and rotational contributions $E_{t r}$ and $E_{\text {rot }}$ were added to the internal energy and entropy:

$$
\begin{aligned}
& H=E_{\mathrm{el}}+\mathrm{E}_{\mathrm{v}}+\mathrm{E}_{\mathrm{tr}}+\mathrm{E}_{\mathrm{rot}}+\mathrm{ZPE}, \\
& S=\mathrm{S}_{\mathrm{el}}+\mathrm{S}_{\mathrm{v}}+\mathrm{S}_{\mathrm{tr}}+\mathrm{S}_{\mathrm{rot} .}
\end{aligned}
$$

All the expressions for enthalpy and entropy contributions are available in Ref. 9. 


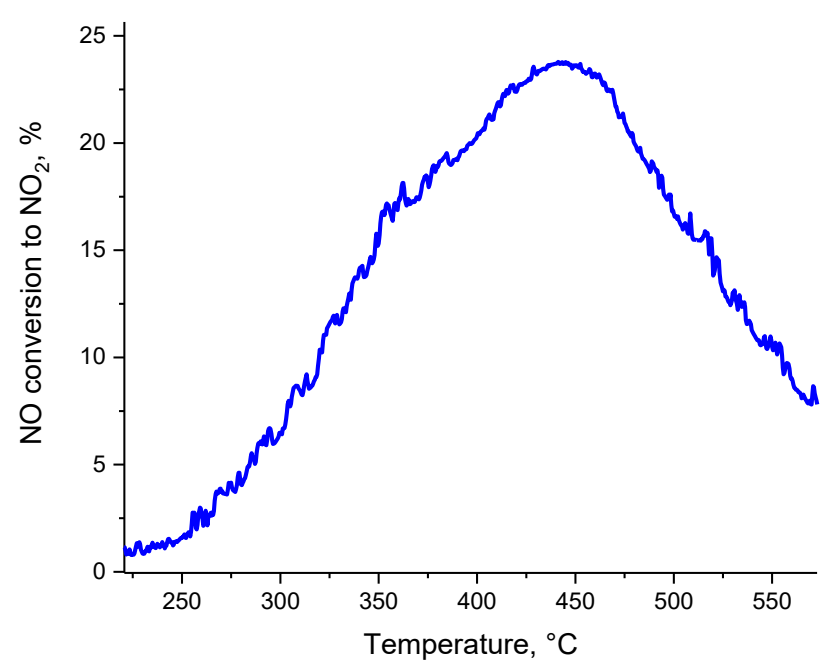

Figure S1. NO oxidation performance of $0.5 \mathrm{wt} \% \mathrm{Pd} / \mathrm{CeO}_{2} .120 \mathrm{mg}$ catalyst, 300 $\mathrm{sscm} / \mathrm{min}$ total flow, GHSV $150 \mathrm{~L} / \mathrm{g}^{*} \mathrm{hr}, 470 \mathrm{ppm} \mathrm{NO}, 13 \% \mathrm{O}_{2}$, balanced in $\mathrm{N}_{2}$.

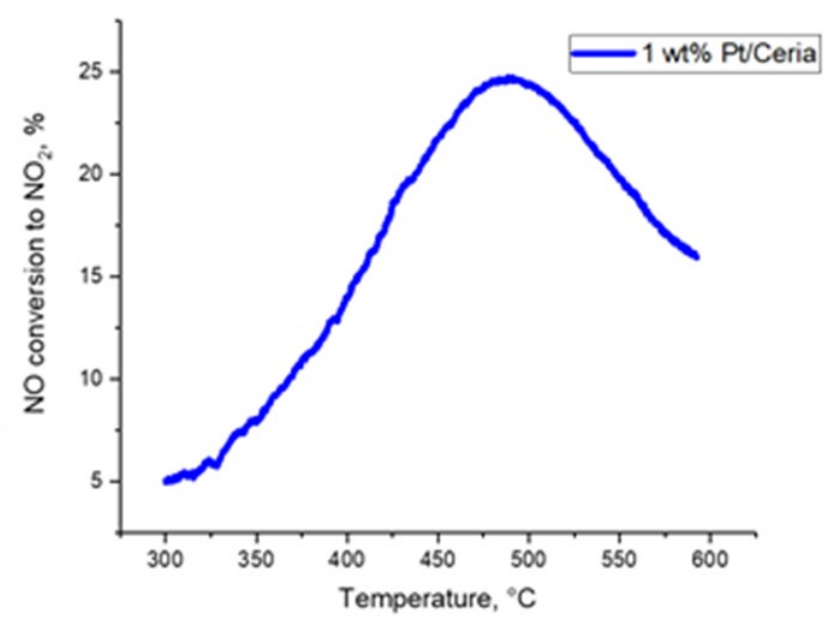

Figure S2. NO oxidation performance of $1 \mathrm{wt} \% \mathrm{Pt} / \mathrm{CeO}_{2} .120 \mathrm{mg}$ catalyst, 300 $\mathrm{sscm} / \mathrm{min}$ total flow, GHSV $150 \mathrm{~L} / \mathrm{g}^{*} \mathrm{hr}, 470 \mathrm{ppm} \mathrm{NO}, 13 \% \mathrm{O}_{2}$, balanced in $\mathrm{N}_{2}$. 


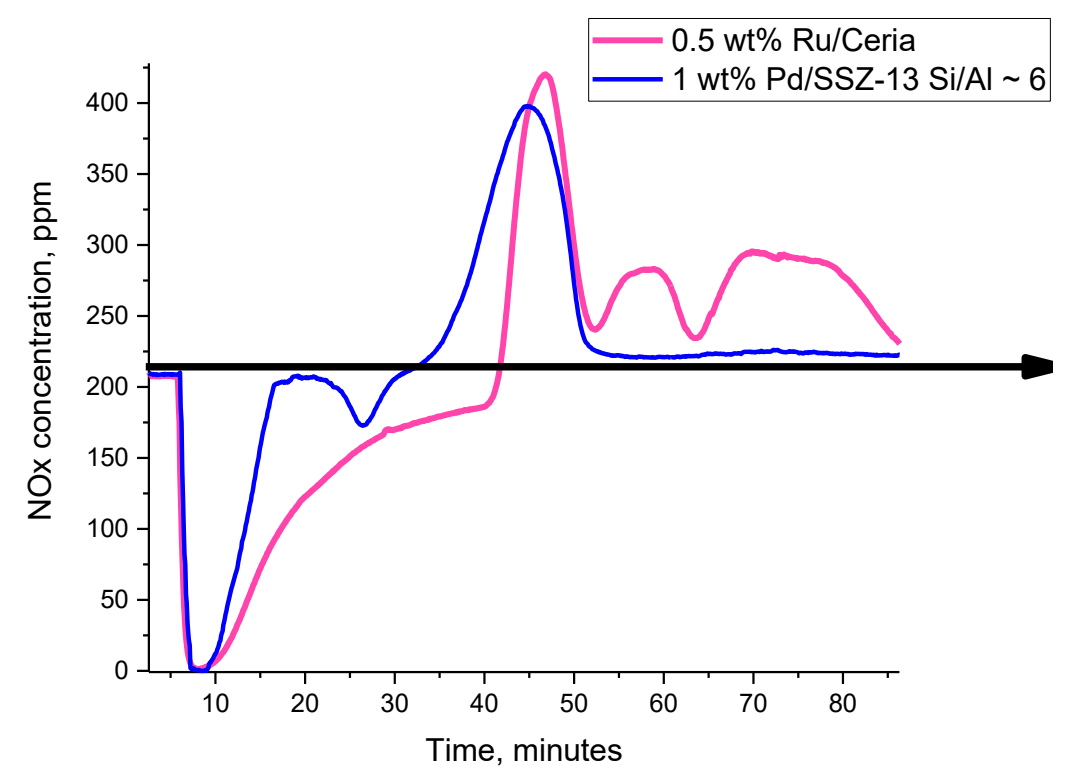

Figure S3. Comparison of PNA performance of $0.5 \mathrm{wt} \% \mathrm{Ru} /$ Ceria and $1 \mathrm{wt} \% \mathrm{Pd} / \mathrm{SSZ} 13$ with Si/Al 6. PNA was performed at $100{ }^{\circ} \mathrm{C}$ at GHSV $150 \mathrm{~L} / \mathrm{g}^{*} \mathrm{~h}$ and conditions identical to Figs. 1 and 2 . Note in the case of $P d / S S Z-13$, ramp rate of $10 \mathrm{~K} / \mathrm{min}$ was started at the $15 \mathrm{~min}$ mark, while for $0.5 \mathrm{wt} \%$ Ru/Ceria sample it was started at the 36 min mark.

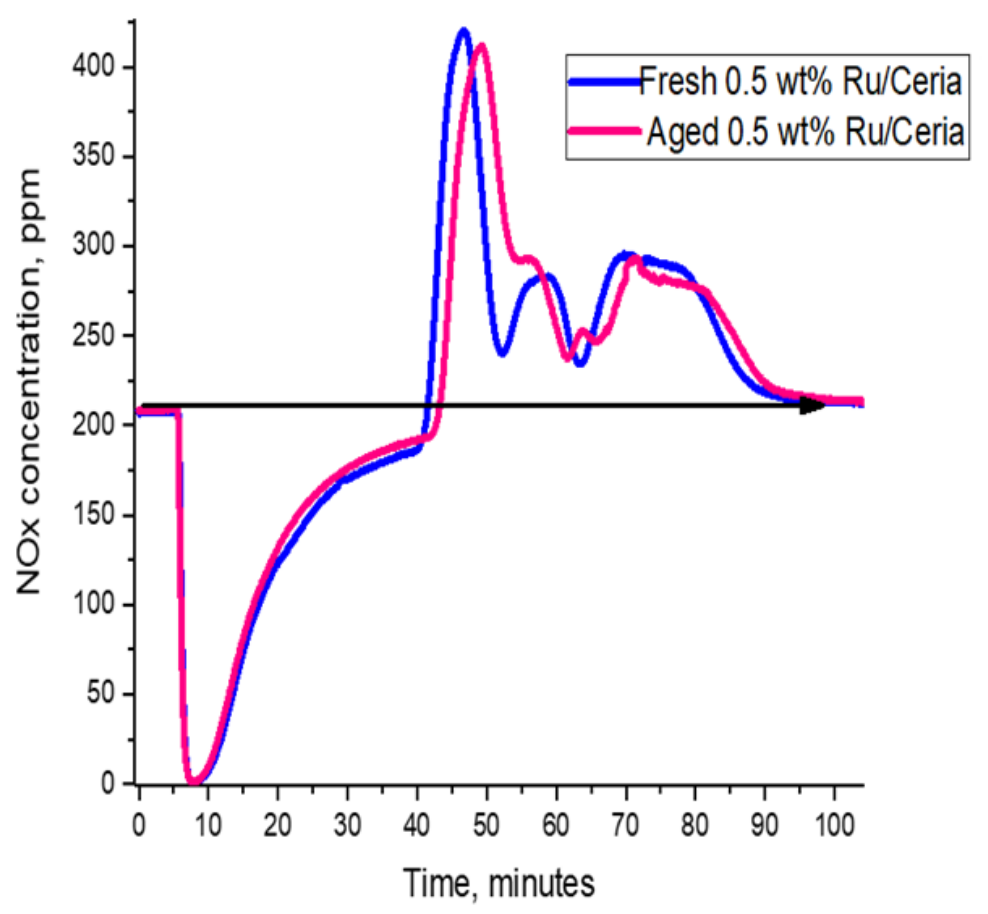

Figure S4. Comparison of PNA performance of $0.5 \mathrm{wt} \% \mathrm{Ru} / \mathrm{Ceria}$ before and after hydrothermal aging (the sample was aged at $750{ }^{\circ} \mathrm{C}$ in the flow of $\mathrm{O}_{2} / \mathrm{H} 2 \mathrm{O}$ and GHSV $\sim 150$ $\mathrm{L} / \mathrm{g}^{*} \mathrm{hr}$ ). PNA was performed at $100{ }^{\circ} \mathrm{C}$ at GHSV $\sim 150 \mathrm{~L} / \mathrm{g}^{*} \mathrm{~h}$ and conditions identical to Fig. 3. Note in the case of fresh $0.5 \mathrm{wt} \% \mathrm{Ru} /$ Ceria sample ramp rate $(10 \mathrm{~K} / \mathrm{min})$ was started at the 36 min mark. For the aged sample, ramp was started at 37.5 min mark. 


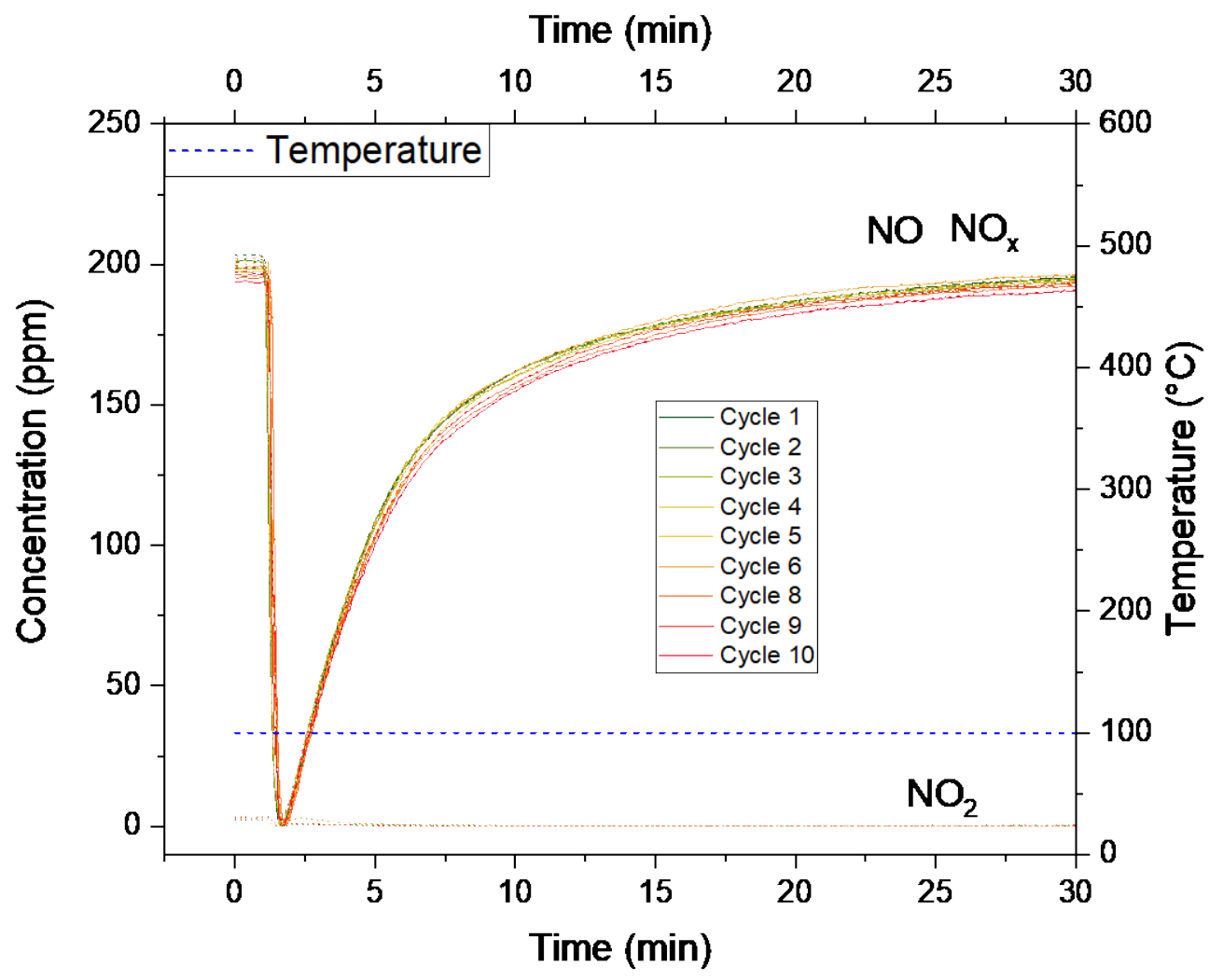

Figure S5. Adsorption part (30 minutes) for 10 consecutive cycles of NO adsorption over 0.25 $\mathrm{wt} \% \mathrm{Ru}_{1} / \mathrm{CeO}_{2}$ at $100{ }^{\circ} \mathrm{C}$. GHSV $150 \mathrm{~L} / \mathrm{g}^{*} \mathrm{hr}$. $\sim 200 \mathrm{ppm} \mathrm{NO}, 2,000 \mathrm{ppm} \mathrm{CO}, 12 \% \mathrm{O}_{2}, \sim 3 \%$ $\mathrm{H}_{2} \mathrm{O}$. 


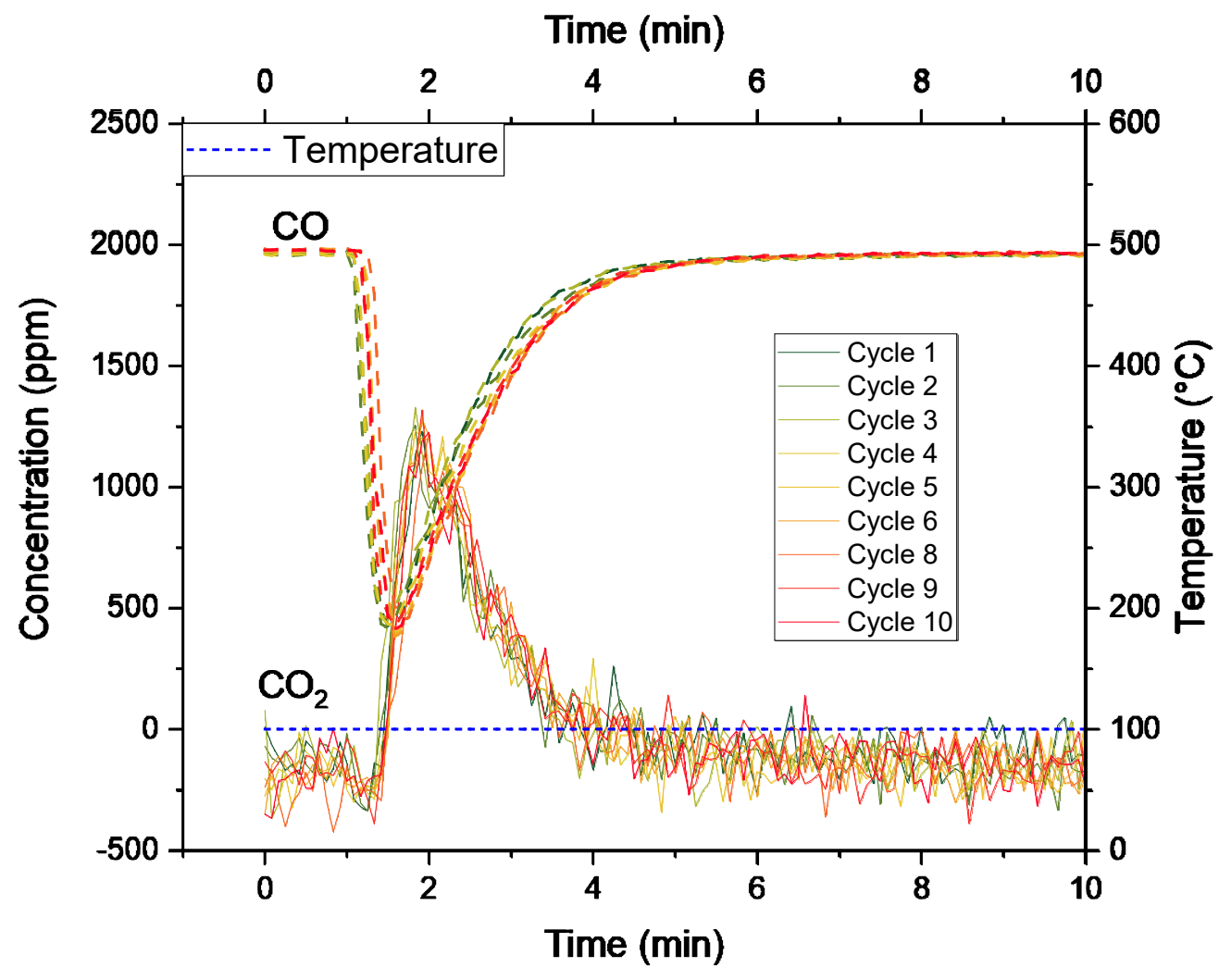

Figure S6. $\mathrm{CO}$ and $\mathrm{CO}_{2}$ profiles during the adsorption part for 10 consecutive cycles of $\mathrm{NO}$ adsorption over $0.25 \mathrm{wt} \% \mathrm{Ru}_{1} / \mathrm{CeO}_{2}$ at $100{ }^{\circ} \mathrm{C}$. GHSV $150 \mathrm{~L} / \mathrm{g}^{*} \mathrm{hr}$. $\sim 200 \mathrm{ppm} \mathrm{NO}, 2,000 \mathrm{ppm}$ $\mathrm{CO}, 12 \% \mathrm{O}_{2}, \sim 3 \% \mathrm{H}_{2} \mathrm{O}$.

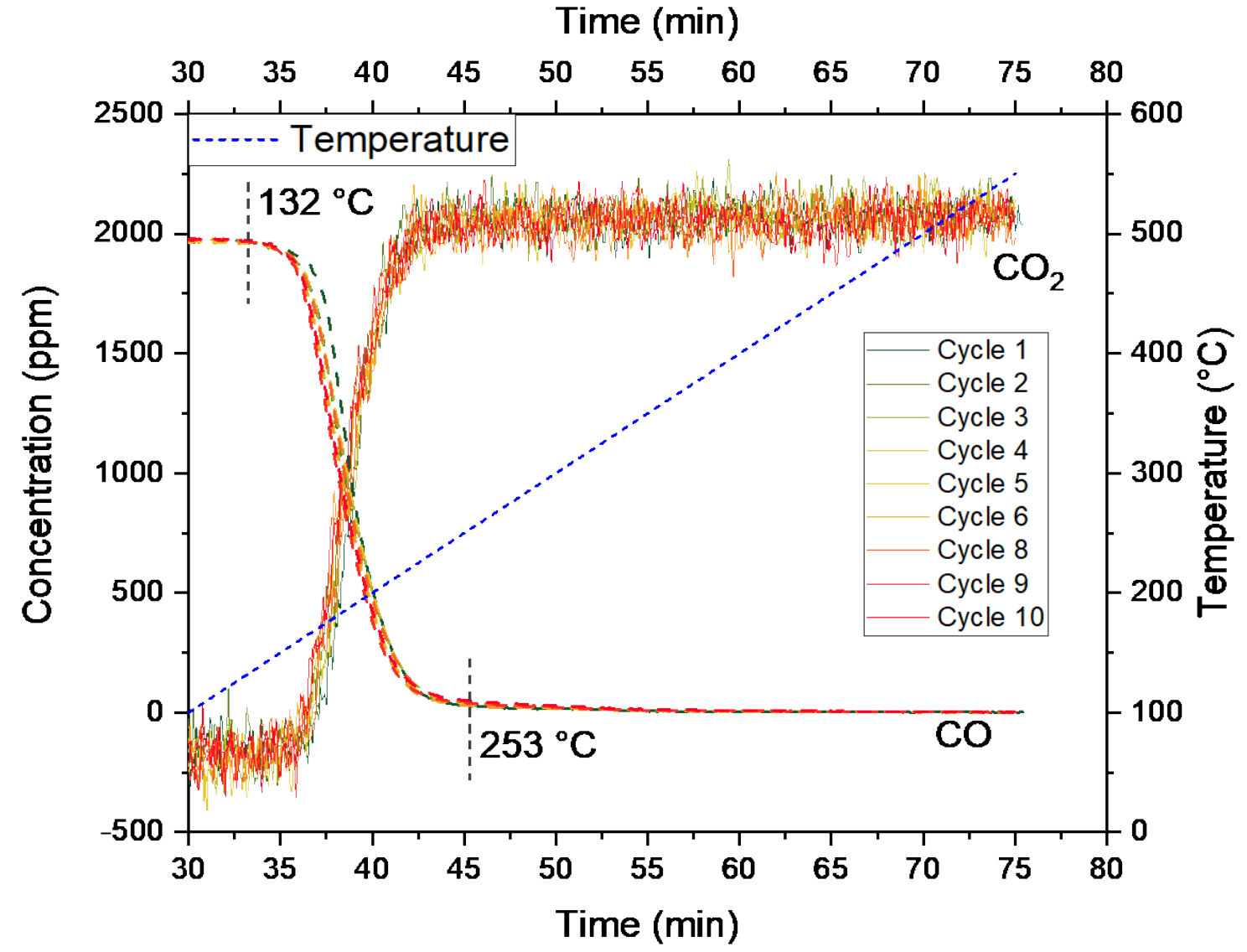


Figure S7. $\mathrm{CO}$ and $\mathrm{CO}_{2}$ profiles during the adsorption part for 10 consecutive cycles of $\mathrm{NO}$ adsorption over $0.25 \mathrm{wt} \% \mathrm{Ru}_{1} / \mathrm{CeO}_{2}$ at $100{ }^{\circ} \mathrm{C}$. GHSV $150 \mathrm{~L} / \mathrm{g}^{*} \mathrm{hr}$. $\sim 200 \mathrm{ppm} \mathrm{NO}, 2,000 \mathrm{ppm}$ $\mathrm{CO}, 12 \% \mathrm{O}_{2}, \sim 3 \% \mathrm{H}_{2} \mathrm{O}$

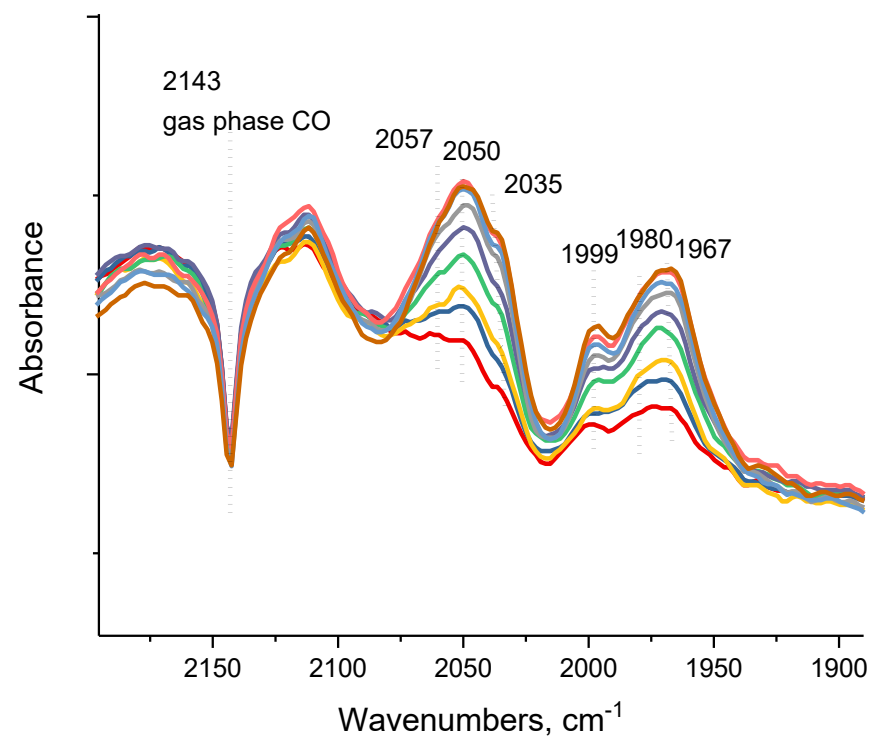

Figure S8. FTIR during CO adsorption (0.7 Torr equilibrium pressure) on $0.5 \mathrm{wt} \%$ Ru/ceria.

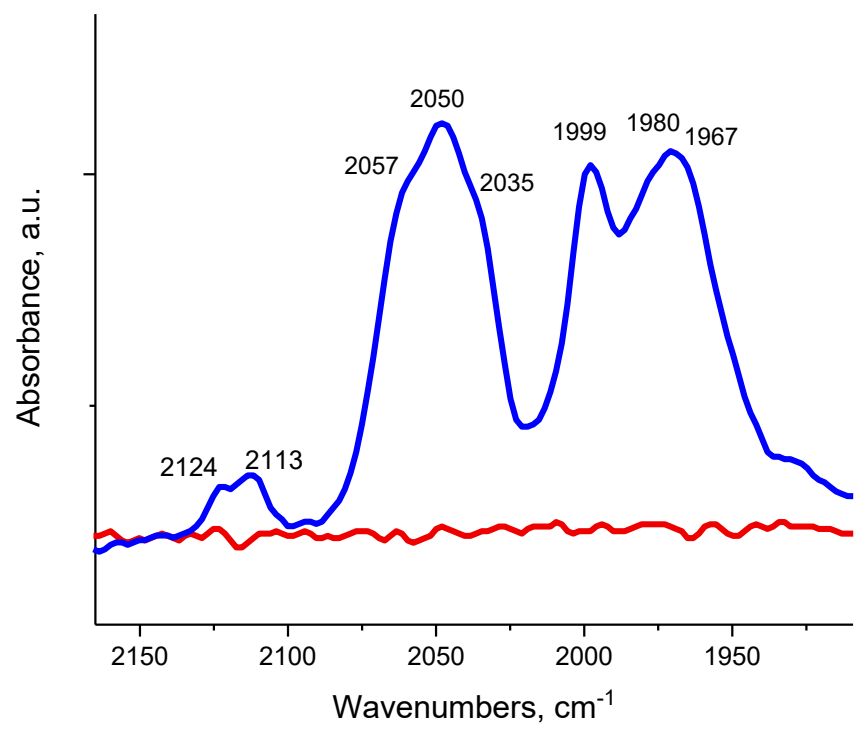


Figure S9. FTIR showing the CO region after applying high vacuum on the sample in Fig. S2. The bands at 2124 and $2113 \mathrm{~cm}^{-1}$, obscured by the gas-phase CO bands in Fig. S2, are visible in this spectrum. The observed band-structure is very similar to $\mathrm{Ru}(\mathrm{II}) /$ Zeolite system after $\mathrm{CO}$ adsorption, in which a mixture of di- and tricarbonyls of Ru forms.

\section{Continuous experiment for $0.25 \mathrm{wt} . \% \mathrm{Ru} /$ Ceria in DRIFTS cell}

\section{Pretreatment under $\mathrm{O}_{2} / \mathrm{He}$ at $500 \mathrm{C}$}

1. Cooling to RT under He

2. $\mathrm{NO}+\mathrm{O}_{2}$ adsorption at $\mathrm{RT}$

3. Heating from RT to $350 \mathrm{C}$ under $\mathrm{NO}+\mathrm{O}_{2}$ (To confirm temperature of $\mathrm{NO}$ oxidation)

4. Purging adsorbed species on catalyst with $\mathrm{O}_{2} / \mathrm{He}$ at $350 \mathrm{C}$, TPD from 350 to $500 \mathrm{C}$ (To confirm $\mathrm{NO}_{2}$ formation)

5. Cooling to $200 \mathrm{C}$ under $\mathrm{He}$

6. Sequential $\mathrm{NO}, \mathrm{NO}+\mathrm{O}_{2}$ adsorption and subsequent purging with $\mathrm{O}_{2} / \mathrm{He}$ at $200 \mathrm{C}$

7. TPD from 200 to $500 \mathrm{C}$ under $\mathrm{O}_{2} / \mathrm{He}$

$\mathrm{NO}+\mathrm{O}_{2}$ adsorption on 0.25 wt. \% Ru/Ceria at RT

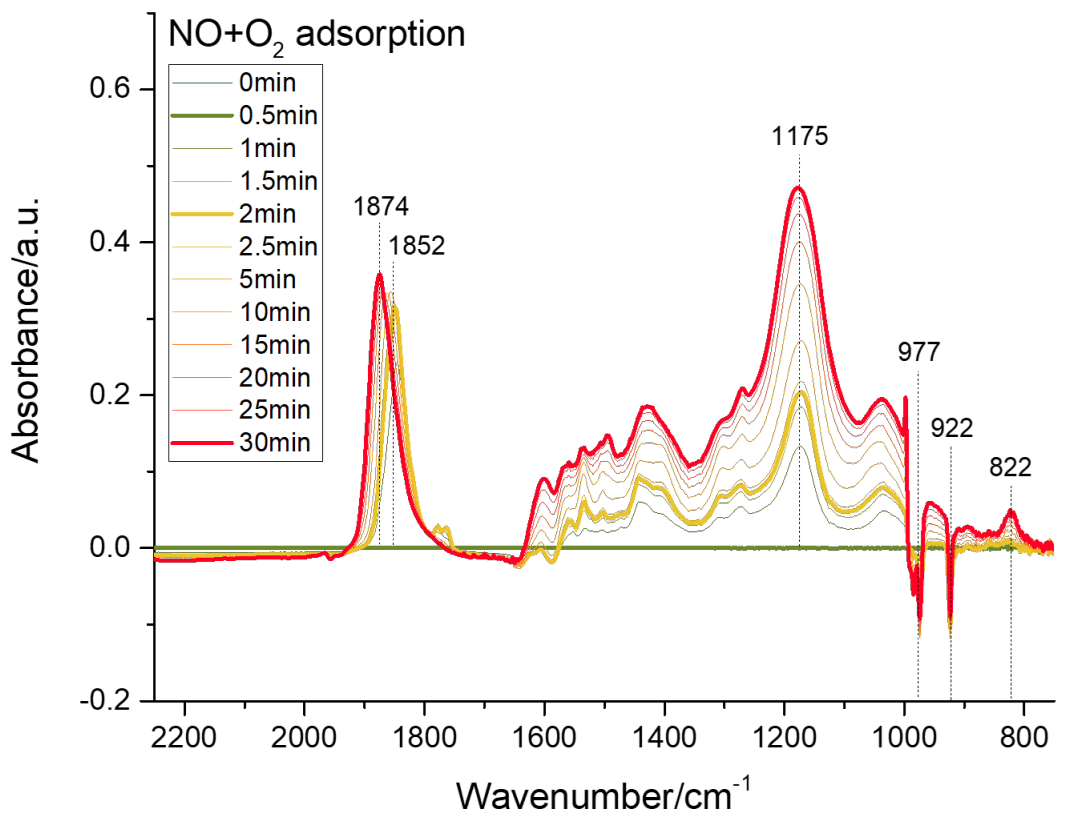

Figure S10. In-situ DRIFTS during flow of $\mathrm{NO}(500 \mathrm{ppm})$ and $\mathrm{O}_{2}(12 \%)$ over 0.25 $\mathrm{wt} \% \mathrm{Ru} /$ ceria at room temperature. $\sim 1170 \mathrm{~cm}^{-1}$ band is due to nitrite formation. 


\section{Heating from $\mathrm{RT}$ to $350 \mathrm{C}$ under $\mathrm{NO}+\mathrm{O}_{2}$ flow}
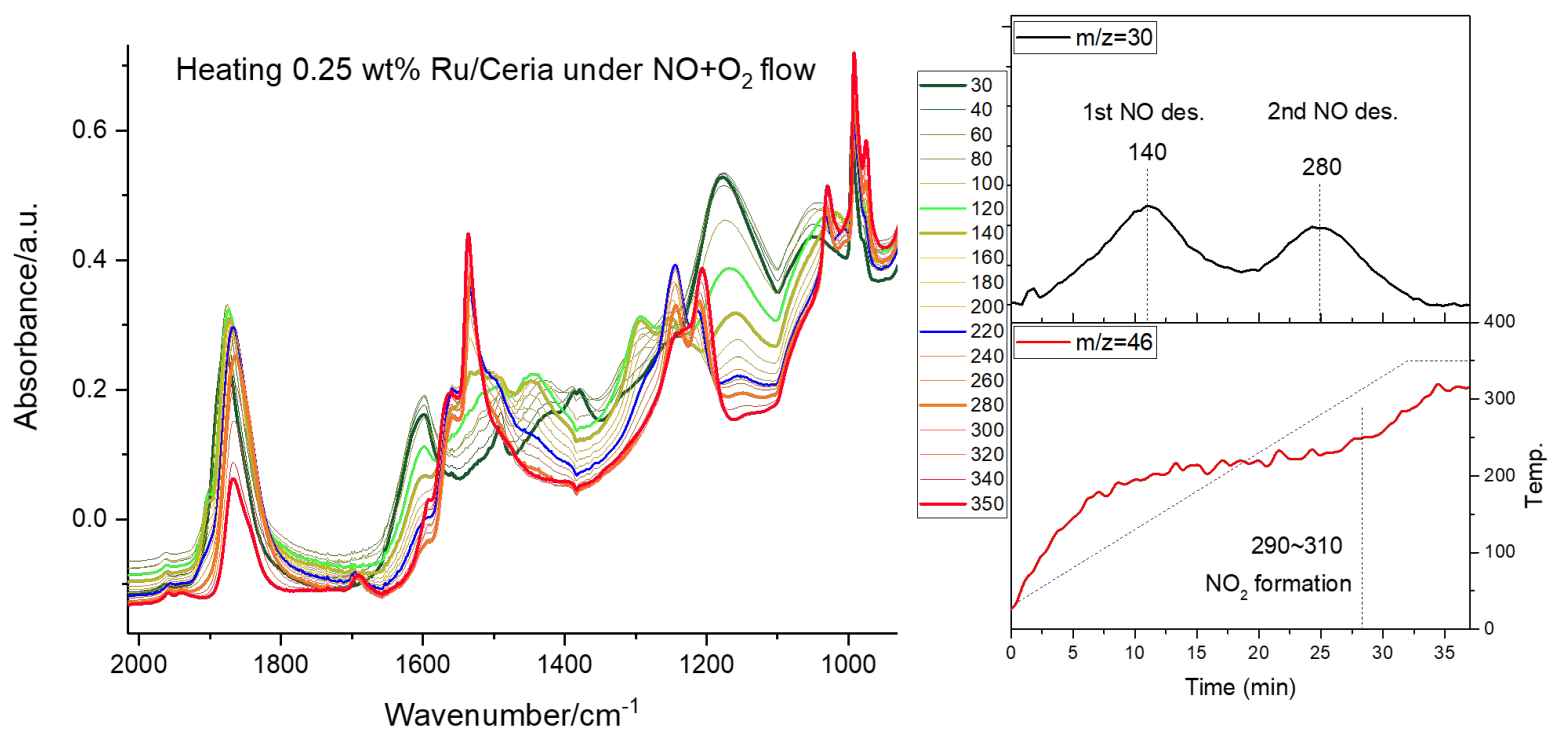

Figure S11. In-situ DRIFTS during flow of $\mathrm{NO}(500 \mathrm{ppm})$ and $\mathrm{O}_{2}(12 \%)$ over 0.25 $\mathrm{wt} \% \mathrm{Ru} / \mathrm{ceria}$ from room temperature to $350{ }^{\circ} \mathrm{C}$ coupled with Mass Spectroscopy measurements (GHSV $150 \mathrm{~L} / \mathrm{g}^{*} \mathrm{hr}$ ). $\mathrm{NO}_{2}$ formation occurs with a maximum at $\sim 350{ }^{\circ} \mathrm{C}$.

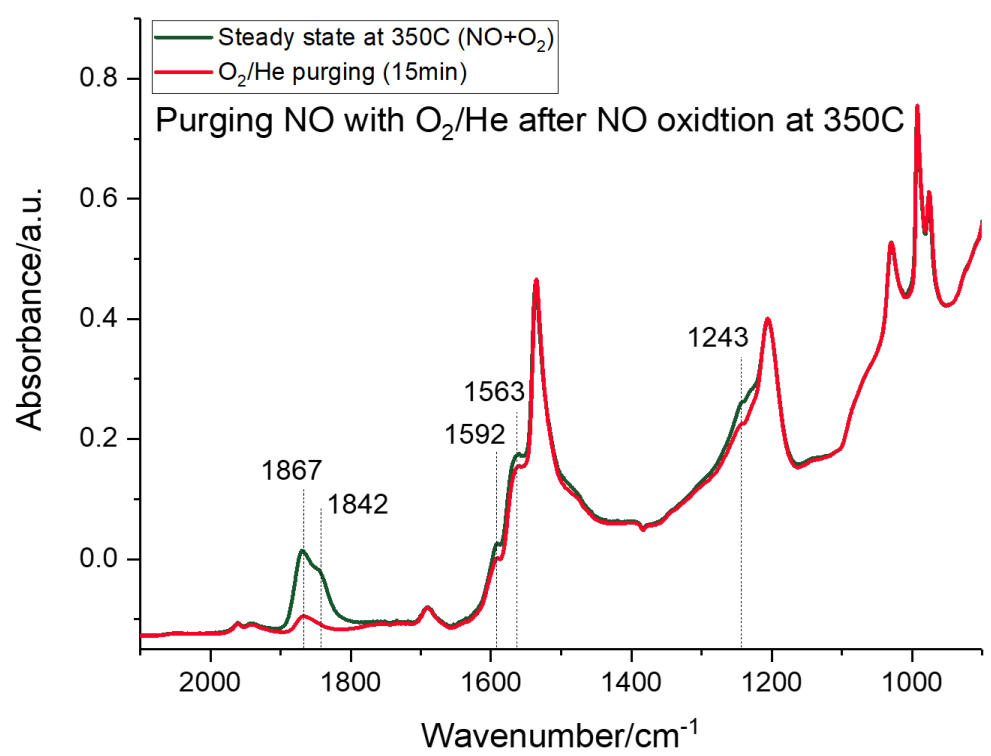

Figure S12. In-situ DRIFTS during flow of $\mathrm{O}_{2}(12 \%)$ in He purge at $350{ }^{\circ} \mathrm{C}$ over 0.25 wt\% Ru/ceria (GHSV 150 L/g*hr). 


\section{Decomposition of Nitrate species under $\mathrm{O}_{2} / \mathrm{He}$ flow}
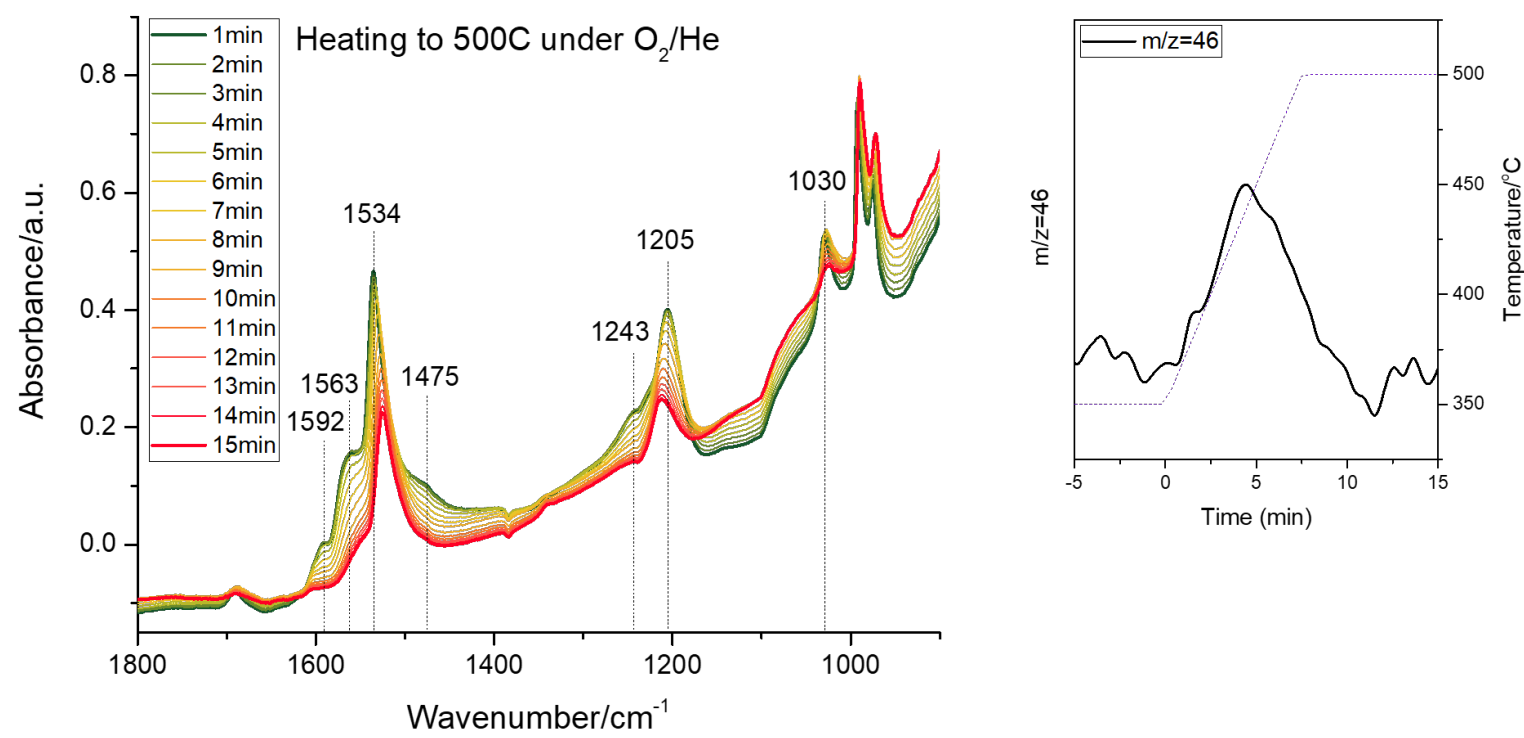

Figure S13. In-situ DRIFTS during flow of $\mathrm{O}_{2}(12 \%)$ in from $350{ }^{\circ} \mathrm{C}$ to $500{ }^{\circ} \mathrm{C}$ over $0.25 \mathrm{wt} \% \mathrm{Ru} / \mathrm{ceria}$ (GHSV $150 \mathrm{~L} / \mathrm{g}^{*} \mathrm{hr}$ ). $\mathrm{NO}_{2}$ is formed during nitrate decomposition.

Re-formation of Nitrate species by purging NO from sequential $\mathrm{NO}$ and $\mathrm{O}_{2}$ addition at $200 \mathrm{C}$

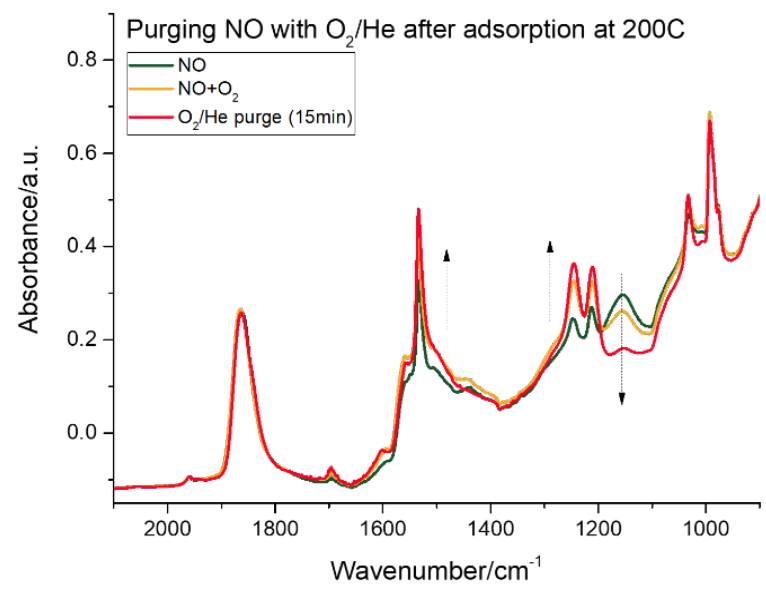

- Figure S14. In-situ DRIFTS at $200{ }^{\circ} \mathrm{C}$ over 0.25 wt\% Ru/ceria (GHSV 150 $\mathrm{L} / \mathrm{g}^{*} \mathrm{hr}$ ). After TPD to $500{ }^{\circ} \mathrm{C}$ (Fig. S13), catalyst was cooled to $200{ }^{\circ} \mathrm{C}$ under $\mathrm{He}$ flow, and subsequently exposed to the described gases sequentially. 


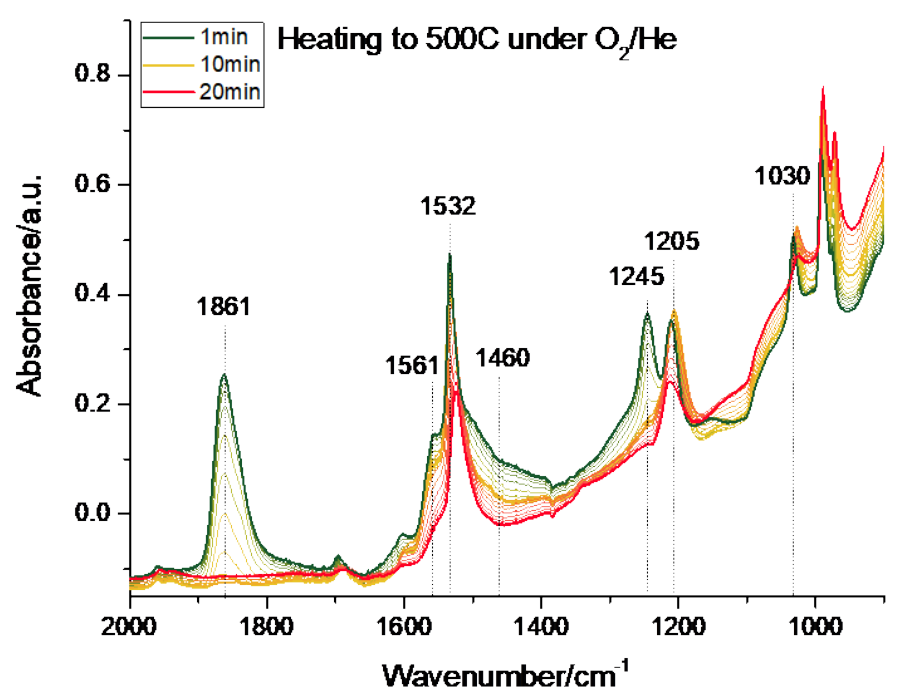

Figure S15. In-situ DRIFTS (after treatment in Fig. S14) from 200 to $500{ }^{\circ} \mathrm{C}$ over 0.25 wt\% Ru/ceria (GHSV $150 \mathrm{~L} / \mathrm{g}^{*} \mathrm{hr}$ ). $\mathrm{NO}_{2}$ forms through nitrate decomposition

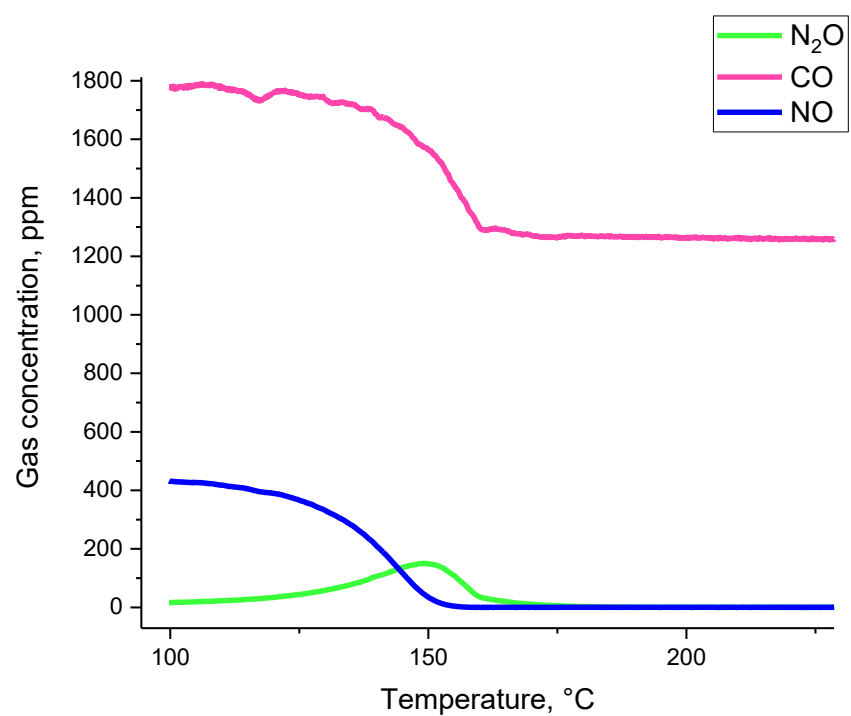

Figure S16. TWC performance of $0.5 \mathrm{wt} \% \mathrm{Ru}_{1} / \mathrm{CeO}_{2}$ for dry $\mathrm{CO}+\mathrm{NO}$ reaction. $120 \mathrm{mg}$ catalyst, $300 \mathrm{sscm} / \mathrm{min}$ total flow, GHSV $150 \mathrm{~L} / \mathrm{g}^{*} \mathrm{hr}, 470 \mathrm{ppm}$ NO, $1750 \mathrm{ppm}$ CO, balanced in $\mathrm{N}_{2}$. 


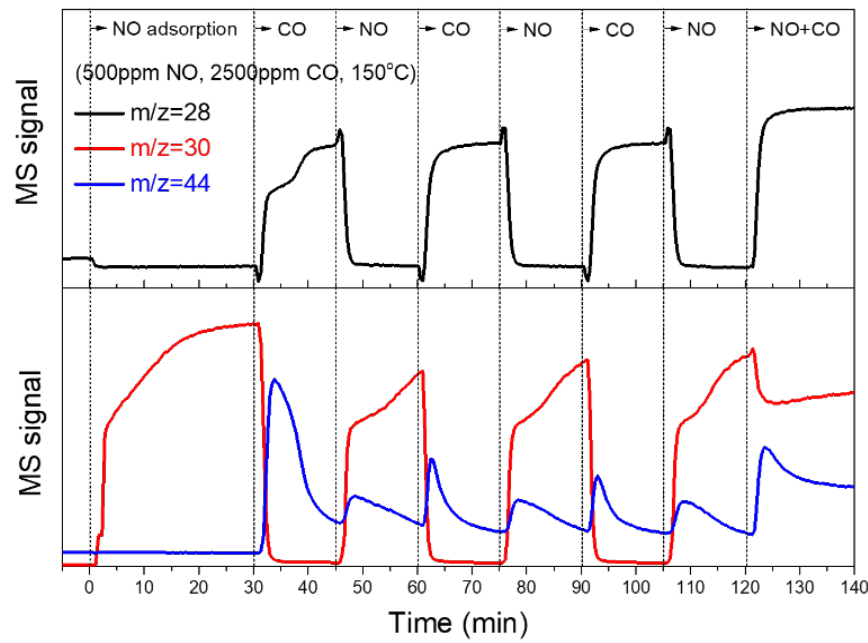

After pretreatment at $500 \mathrm{C}$ in $3 \% \mathrm{O}_{2} / \mathrm{He}$, cell was cooled to $150 \mathrm{C}$.

$500 \mathrm{ppm}$ of $\mathrm{NO}$ was adsorbed for $30 \mathrm{~min}$.

After cutoff NO, 2500ppm of CO was

introduced for $15 \mathrm{~min}$. In this stage, CO

adsorption and $\mathrm{CO}_{2}$ formation was observed.

(Reduction cycle)

After cutoff $\mathrm{CO}, \mathrm{NO}$ was introduced for $15 \mathrm{~min}$ In this stage, adsorption and reaction of $\mathrm{NO}$

occurred with some $\mathrm{CO}_{2}\left(\mathrm{~N}_{2} / \mathrm{N}_{2} \mathrm{O}\right)$ formation.

(Oxidation cycle)

This modulation was repeated 3 times.

Lastly, NO and CO was co-flowed to achieve $\sim 30 \%$ NO conversion in DRIFTS cell. (Total flow rate: $50 \mathrm{ml} / \mathrm{min}$ )

Figure S17. Summary of CO-NO excitation-modulation experiments over $0.25 \mathrm{wt} \%$ $\mathrm{Ru}_{1} / \mathrm{CeO}_{2}$ in the in-situ DRIFTS cell with effluent going into Mass Spectrometer. Those sequential experiments are presented in Figs. S18, Fig. 8 A and B (Main text)

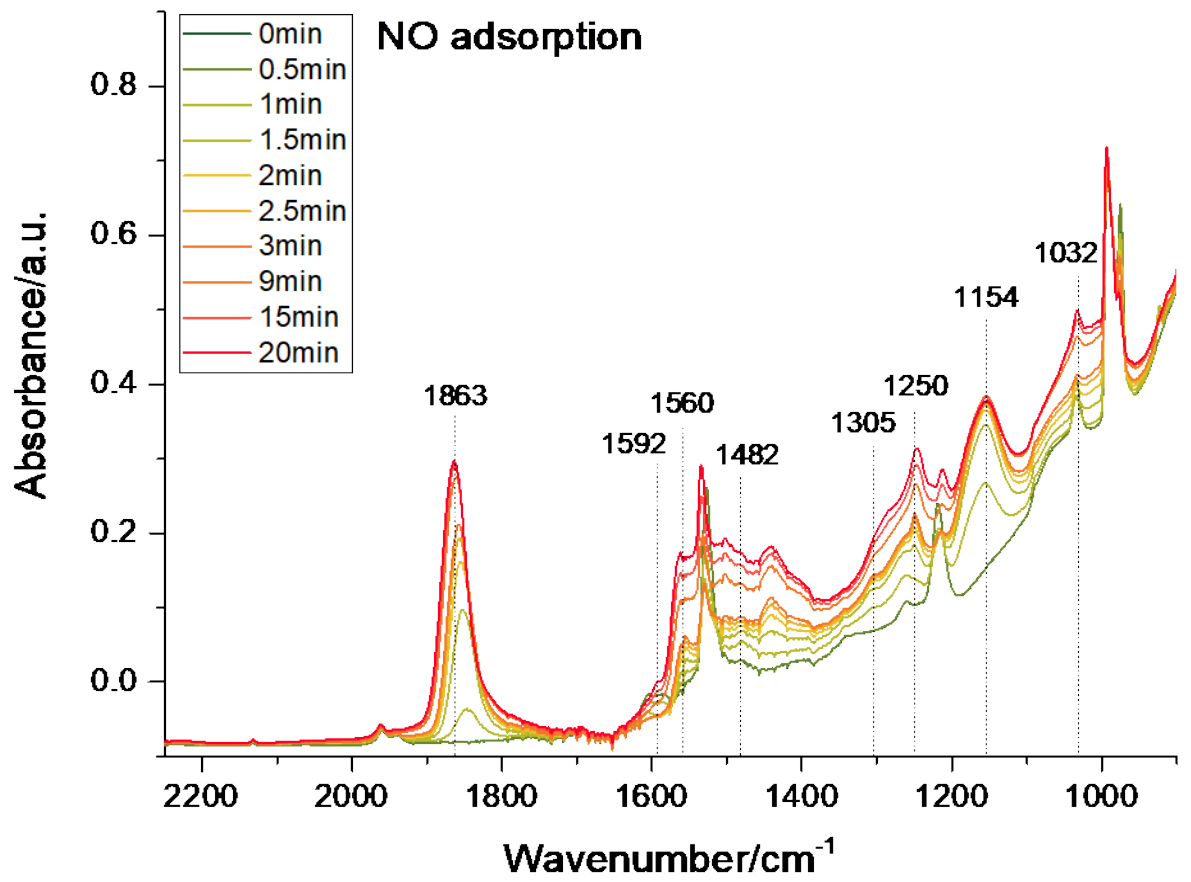

Figure $\mathrm{S} 180.25 \mathrm{wt} \% \mathrm{Ru}_{1} / \mathrm{CeO}_{2}$ in-situ DRIFTS during NO flow. The 1 st cycle of $\mathrm{CO}-$ $\mathrm{NO}$ showing spectral modulations upon gas-phase changes is shown in Fig. $8 \mathrm{~A}$ and $\mathrm{B}$ (sequential experiments). 

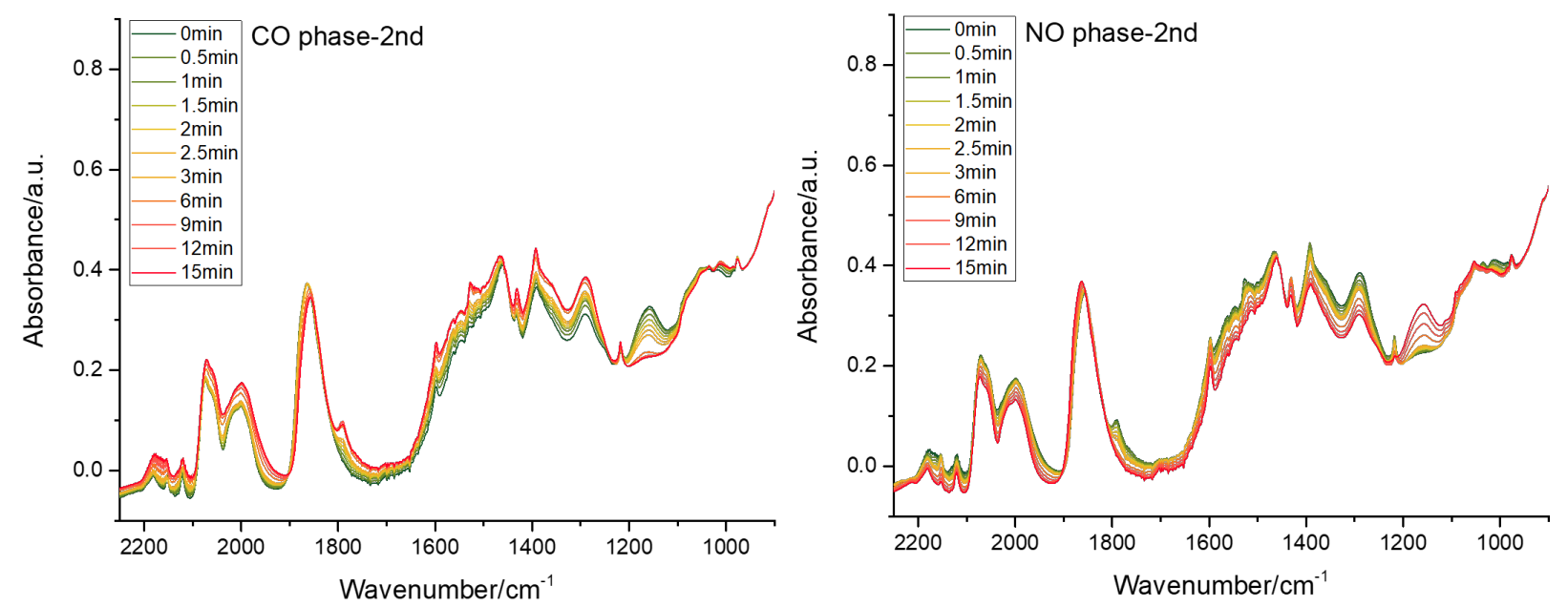

Figure S19. $0.25 \mathrm{wt} \% \mathrm{Ru}_{1} / \mathrm{CeO}_{2}$ in-situ DRIFTS the 2 nd cycle of CO-NO in-situ drifts showing spectral modulations upon gas-phase changes; those experiments were sequentially done after the experiment in Fig. 8B (the end of the 1st cycle).

\section{Repeated $3^{\text {rd }} \mathrm{CO}$ and NO cycle}
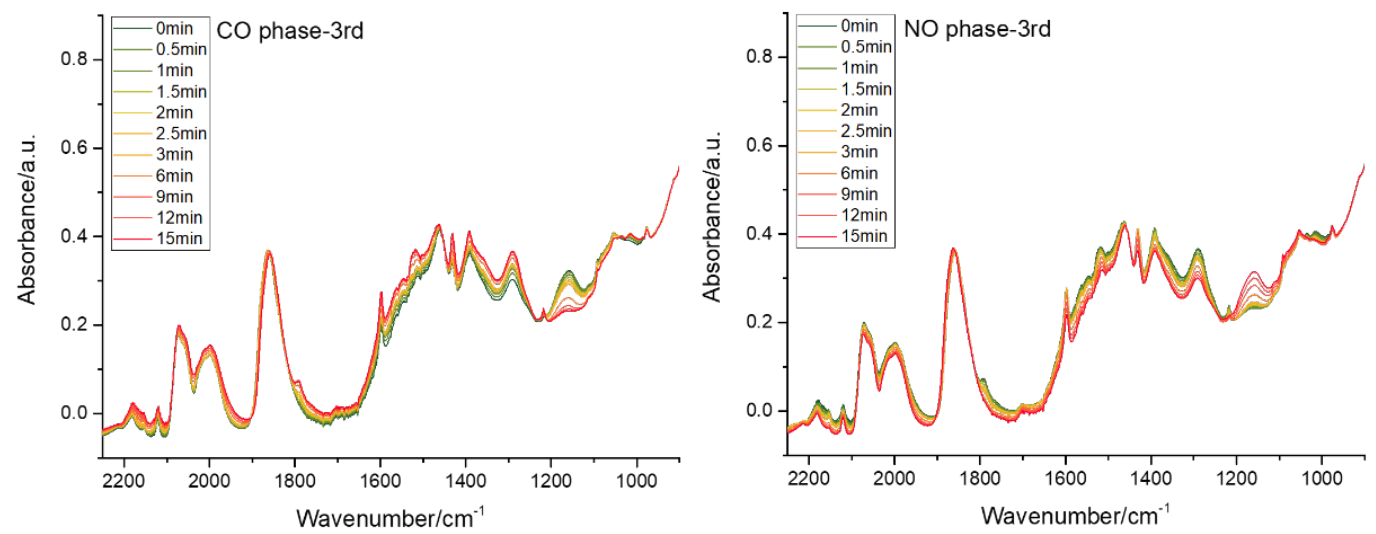

Figure S20. $0.25 \mathrm{wt} \% \mathrm{Ru}_{1} / \mathrm{CeO}_{2}$ in-situ DRIFTS the 3rd cycle of CO-NO in-situ drifts showing spectral modulations upon gas-phase changes; those experiments were sequentially done after the last experiment in Fig. S18. 


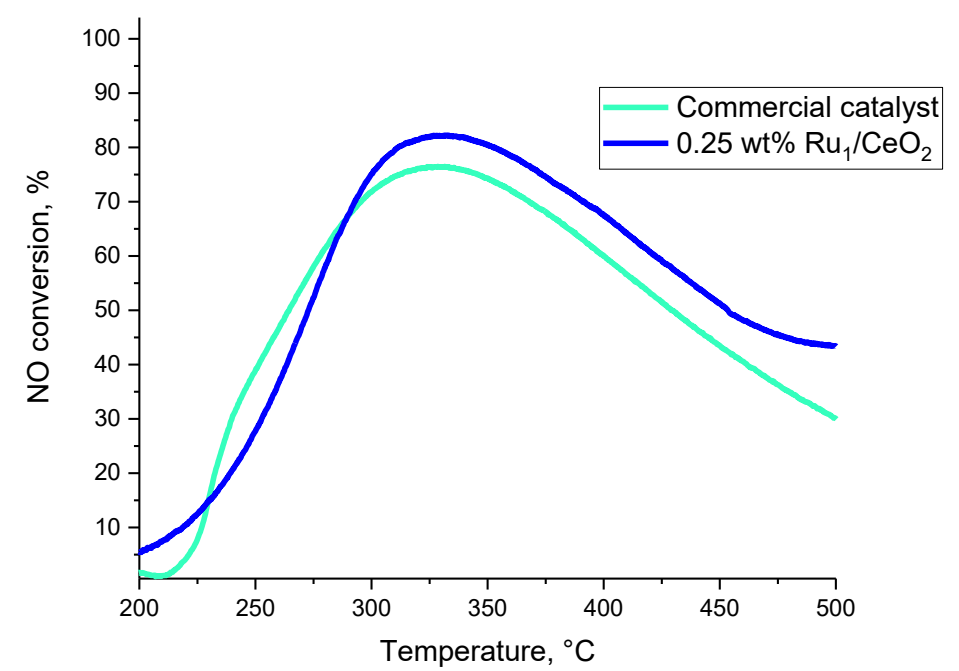

Figure S21. Comparison of NO oxidation performance of the commercial catalyst and $0.25 \mathrm{wt} \% \mathrm{Ru}_{1} / \mathrm{CeO}_{2}$ (both catalysts were hydrothermally aged at $750{ }^{\circ} \mathrm{C}$ in the presence of air $/ 10 \% \mathrm{H}_{2} \mathrm{O}$ for 16 hours prior to measurements): $120 \mathrm{mg}$ catalyst, temperature: starting at $500{ }^{\circ} \mathrm{C}$ down to $200{ }^{\circ} \mathrm{C}$ with a down-ramp of $2 \mathrm{~K} / \mathrm{min}$. $\sim 200$ ppm NO, 2,000 ppm CO, $12 \% \mathrm{O}_{2}, \sim 3 \% \mathrm{H}_{2} \mathrm{O}$. GHSV $150 \mathrm{~L} / \mathrm{g}^{*} \mathrm{hr}$.

Table S1. BET Surface areas of various synthesized samples.

\begin{tabular}{|l|l|}
\hline Sample & BET area, $\mathrm{m}^{2} / \mathrm{g}$ \\
\hline Ceria & 98 \\
\hline Ceria calcined $800{ }^{\circ} \mathrm{C}$ & 11 \\
\hline $0.5 \mathrm{Ru} /$ Ceria calcined $800{ }^{\circ} \mathrm{C}$ & 44 \\
\hline $1 \mathrm{Pt} /$ Ceria calcined $800{ }^{\circ} \mathrm{C}$ & 38 \\
\hline $0.5 \mathrm{Pd} /$ Ceria calcined $800{ }^{\circ} \mathrm{C}$ & 36 \\
\hline $0.1 \mathrm{Ru} /$ Ceria calcined $800{ }^{\circ} \mathrm{C}$ & 40 \\
\hline
\end{tabular}


Energetic and structural characteristics of the $\mathrm{RuO}(\mathrm{NO}) / \mathrm{Ce}_{21} \mathrm{O}_{42}$ and $\mathrm{RuO}(\mathrm{NO}) / \mathrm{Ce}_{21} \mathrm{O}_{41}$ complexes (i.e. without and with created $\mathrm{O}$ vacancy in the ceria support, respectively). Energy values are in eV, distances in $\mathrm{pm}$, and vibrational frequencies in $\mathrm{cm}^{-1}$.

\begin{tabular}{|l|c|c|c|c|c|c|c|c|c|c|c|}
\hline RuO(NO)/Ce $e_{21} \mathrm{O}_{42}$ & $\mathrm{E}_{\text {rel }}{ }^{\mathrm{a}}$ & $\mathrm{BE}^{\mathrm{b}}$ & $\mathrm{E}_{\text {vac }}$ & $\mathrm{N}_{\mathrm{s}}^{\mathrm{c}}$ & $\mathrm{N}_{\mathrm{s}}(\mathrm{Ru})^{\mathrm{d}}$ & $\#\left(\mathrm{Ce}^{3+}\right)^{\mathrm{e}}$ & $\mathrm{q}(\mathrm{Ru})^{\mathrm{h}}$ & $\mathrm{Ru}-\mathrm{O}$ & $\mathrm{Ru}-\mathrm{N}$ & $\Delta(\mathrm{N}-\mathrm{O})^{\mathrm{f}}$ & $v(\mathrm{~N}-\mathrm{O})^{\mathrm{g}}$ \\
\hline a-1O_NO & 1.72 & -3.11 & & 1 & 0.8 & 0 & 1 & $184 ; 190$ & 179 & 2.3 & 1763 \\
\hline b-1O_NO & 2.91 & -1.03 & & 1 & 0.7 & 0 & 1 & $185 ; 209 ; 224$ & 177 & 1.7 & 1799 \\
\hline c-1O_NO & 1.42 & -2.26 & & 1 & 0.7 & 0 & 1 & $195 ; 200 ; 204$ & 177 & 1.4 & 1824 \\
\hline d-1O_NO & 1.91 & -1.65 & & 1 & 0.7 & 0 & 1 & $182 ; 190$ & 178 & 2.7 & 1733 \\
\hline e-1O_NO & 0.00 & -3.00 & & 1 & 0 & 1 & 2 & $191 ; 212 ; 213 ; 213 ; 213$ & 179 & 1.1 & 1840 \\
\hline e-1O_NO_vac_a & 0.00 & & 1.24 & 3 & 0.25 & 3 & 2 & $198 ; 199 ; 202 ; 204$ & 173 & 2.4 & 1788 \\
\hline e-1O_NO_vac_b & 2.08 & & 3.32 & 1 & 0 & 3 & 2 & $192 ; 212 ; 212 ; 214 ; 215$ & 178 & 1.2 & 1832 \\
\hline e-1O_NO_vac_c & 0.63 & & 1.86 & 1 & 0 & 3 & 2 & $191 ; 212 ; 212 ; 212 ; 213$ & 178 & 1.1 & 1837 \\
\hline
\end{tabular}

${ }^{a}$ Relative energy (in $\mathrm{eV}$ ) with respect to the most stable structure in each series. ${ }^{\mathrm{b}}$ Binding energy (in $\mathrm{eV}$ ) of the adsorbed NO ligand. ${ }^{\mathrm{c}}$ Number of unpaired electrons in the system. ${ }^{\mathrm{d}}$ Number of unpaired electrons in $\mathrm{Ru} .{ }^{\mathrm{e}}$ Number of $\mathrm{Ce}^{3+}$ ions in the ceria nanoparticle. ${ }^{\mathrm{f}}$ Elongation of $\mathrm{N}-\mathrm{O}$ bond upon adsorption with respect to the calculated bond length in gas-phase NO of $116.9 \mathrm{pm} .{ }^{\mathrm{g}}$ Calculated N-O vibrational frequencies. ${ }^{\mathrm{h}}$ Formal charge of $\mathrm{Ru}$.

\section{Table S3}

Electronic and Gibbs free energies and barriers (given in parenthesis) of the reaction steps for NO oxidation on the most stable $\mathrm{RuO} / \mathrm{Ce}_{21} \mathrm{O}_{42}$ complexes, e- $1 \mathrm{O}$ and c-1O, where $\mathrm{RuO}$ species are located at the (100) and (111) facets of the $\mathrm{Ce}_{21} \mathrm{O}_{42}$ nanoparticle. All values are in $\mathrm{kJ} / \mathrm{mol}$.

\begin{tabular}{l|cc|cc}
\hline Complex & e-1O & e-1O & $c-10$ & $c-10$ \\
\hline Reaction step & $\Delta \mathrm{E}\left(\mathrm{E}^{\#}\right)$ & $\Delta \mathrm{G}\left(\mathrm{G}^{\#}\right)$ & $\Delta \mathrm{E}\left(\mathrm{E}^{\#}\right)$ & $\Delta \mathrm{G}\left(\mathrm{G}^{\#}\right)$ \\
\hline $\mathrm{CeO}_{2} / \mathrm{Ru}+1 / 2 \mathrm{O}_{2} \rightarrow \mathrm{CeO}_{2} / \mathrm{RuO}$ & -84 & -73 & -277 & -229 \\
$\mathrm{CeO}_{2} / \mathrm{RuO}+\mathrm{NO} \rightarrow \mathrm{CeO}_{2} / \mathrm{RuO}(\mathrm{NO})$ & -290 & -88 & -218 & -80 \\
$\mathrm{CeO}_{2} / \mathrm{RuO}(\mathrm{NO}) \rightarrow \mathrm{CeO}_{2} / \mathrm{Ru}\left(\mathrm{NO}_{2}\right)$ & $184(249)$ & $173(200)$ & $147(182)$ & $146(154)$ \\
$\mathrm{CeO}_{2} / \mathrm{Ru}\left(\mathrm{NO}_{2}\right) \rightarrow \mathrm{CeO}_{2} / \mathrm{Ru}+\mathrm{NO}_{2}$ & 77 & -73 & 236 & 101 \\
\hline
\end{tabular}

1. J. P. Perdew, J. A. Chevary, S. H. Vosko, K. A. Jackson, M. R. Pederson, D. J. Singh and C. Fiolhais, Phys. Rev. B, 1992, 46, 6671-6687; ibid. 1993, 48, 4978-4978.

2. G. Kresse and J. Hafner, Phys. Rev. B, 1993, 47, 558-561.

3. Version VASP.4.9; http://cms.mpi.univie.ac.at/vasp/

4. G. Kresse and D. Joubert, Phys. Rev. B, 1999, 59, 1758-1775. 
5. V. I. Anisimov, F. Aryasetiawan and A. I. Lichtenstein, J. Phys.: Condens. Matter, 1997, 9, 767808.

6. S. L. Dudarev, G. A. Botton, S. Y. Savrasov, C. J. Humphreys and A. P. Sutton, Phys. Rev. B, 1998, 57, 1505-1509.

7. A. Migani, G. N. Vayssilov, S. T. Bromley, F. Illas and K. M. Neyman, Chem. Commun., 2010, 46, 5936-5938.

8. A. Migani, G. N. Vayssilov, S. T. Bromley, F. Illas and K. M. Neyman, J. Mater. Chem., 2010, 20, 10535-10546.

9. J. W. Ochterski, Thermochemistry in Gaussian, 2000, 1-19, www.gaussian.com/g_whitepap/thermo.htm

10. N. Hansen, T. Kerber, J. Sauer, A. T. Bell and F. J. Keil, J. Am. Chem. Soc., 2010, 132, 1152511538.

11. H. A. Aleksandrov and G. N. Vayssilov, Catal. Today, 2010, 152, 78-87. 